\title{
International Conflict Mediation
}

This book examines how new empirical approaches to mediation can shed fresh light on the effectiveness of different patterns of conflict management, and offers guidelines on the process of international mediation.

International conflict mediation has become one of, if not the most prominent and important conflict resolution methods of the early twentyfirst century. This book argues that traditional approaches to understanding mediation have been inadequate, and that in order to really understand how the process of international mediation works, studies need to operate within an explicit theoretical framework, adopt systematic empirical approaches and use a diversity of methods to identify critical interactions, contexts and relationships. This book captures recent important changes in the field of international conflict mediation and includes chapters by leading scholars on a variety of critical aspects of conflict management, using state-of-the-art analytical tools and up-to-date data.

This book will be of great interest to scholars of peace and conflict studies, methods in social science and of international relations in general.

Jacob Bercovitch is Professor of International Relations at the University of Canterbury, New Zealand, and is the author and editor of many books and numerous articles on international conflict resolution. Scott Sigmund Gartner is Professor of Political Science at the University of California, Davis, USA. 


\section{Series: security and conflict management \\ Series Editors: Fen Osler Hampson \\ Carleton University, Canada}

Chester Crocker

Georgetown University, Washington DC

Pamela Aall

United States Institute of Peace, Washington DC

This series will publish the best work in the field of security studies and conflict management. In particular, it will promote leading-edge work that straddles the divides between conflict management and security studies, between academics and practitioners and between disciplines.

\section{Negotiation and Conflict Management}

I. William Zartman

\section{Conflict Management and African Politics}

Negotiation, mediation, and politics

Edited by Terrence Lyons and Gilbert M. Khadiagala

\section{International Conflict Mediation}

New approaches and findings

Edited by Jacob Bercovitch and Scott Sigmund Gartner 


\section{International Conflict Mediation}

New approaches and findings

\section{Edited by Jacob Bercovitch and Scott Sigmund Gartner}


First published 2009

by Routledge

2 Park Square, Milton Park, Abingdon, Oxon OX14 4RN

Simultaneously published in the USA and Canada

by Routledge

270 Madison Ave, New York, NY 10016

Routledge is an imprint of the Taylor $\mathcal{E}$ Francis Group, an informa business

This edition published in the Taylor \& Francis e-Library, 2008.

"To purchase your own copy of this or any of Taylor \& Francis or Routledge's collection of thousands of eBooks please go to www.eBookstore.tandf.co.uk."

(C) 2009 Selection and editorial matter, Jacob Bercovitch and Scott

Sigmund Gartner; individual chapters, the contributors

All rights reserved. No part of this book may be reprinted or reproduced or utilized in any form or by any electronic, mechanical, or other means, now known or hereafter invented, including photocopying and recording, or in any information storage or retrieval system, without permission in writing from the publishers.

British Library Cataloguing in Publication Data

A catalogue record for this book is available from the British Library

Library of Congress Cataloging-in-Publication Data

International conflict mediation : new approaches and findings /

edited by Jacob Bercovitch and Scott Sigmund Gartner.

p. cm. - (Security conflict and management ; 3)

Includes bibliographical references.

1. Conflict management-International cooperation. I. Bercovitch, Jacob. II. Gartner, Scott Sigmund, 1963-

JZ6368.I574 2009

327.1'72-dc22

2008026161

ISBN 0-203-88513-9 Master e-book ISBN

ISBN10: 0-415-45309-7 (hbk)

ISBN10: 0-203-88513-9 (ebk)

ISBN13: 978-0-415-45309-7 (hbk)

ISBN13: 978-0-203-88513-0 (ebk) 
We dedicate this book to Daniella, Jeanette, Liora and Michelle. 



\section{Contents}

List of figures $\quad \mathrm{x}$

List of tables $\quad$ xi

Notes on contributors $\quad$ xiii

Acknowledgments xviii

1 New approaches, methods and findings in the study of mediation

JACOB BERCOVITCH AND SCOTT SIGMUND GARTNER

PART I

Mediation strategy

2 Is there method in the madness of mediation?

Some lessons for mediators from quantitative studies of mediation

JACOB BERCOVITCH AND SCOTT SIGMUND GARTNER

3 Third-party intermediaries and negotiated settlements, 1946-2000

DERRICK V. FRAZIER AND WILLIAM J. DIXON

\section{PART II}

Mediator type

Bias and information

4 Credibility and strategy in international mediation 
viii Contents

5 Mediator types and the effectiveness of information-provision strategies in the resolution of international conflict

BURCU SAVUN

\section{UN and neutrality}

6 Guaranteeing peace: the credibility of third-party mediators in civil wars

ISAK SVENSSON

7 Choosing sides: $\mathrm{UN}$ resolutions and non-neutrality MICHELLE BENSON AND NIL S. SATANA

\section{PART III}

Dispute and crisis types

8 Softening up: making conflicts more amenable to diplomacy

J. MICHAEL GREIG AND PAUL F. DIEHL

9 Power play: mediation in symmetric and asymmetric international crises

DAVID QUINN, JONATHAN WILKENFELD, KATHLEEN SMARICK AND VICTOR ASAL

10 Protracted conflict and crisis mediation: a contingency approach

DAVID CARMENT, YIAGADEESEN SAMY AND SOULEIMA EL ACHKAR

\section{PART IV}

The conflict management environment

11 Practicing democratic community norms: third-party conflict management and successful settlements 
12 Philippine and Taiwanese legal mediation 265 JAMESA. WALL, WAN YAN, TSUNGTING CHUNG AND DANIEL DRUCKMAN

\section{PART V}

Data

13 Conflict and Mediation Event Observations (CAMEO): an event data framework for a post-Cold War world

DEBORAH J. GERNER, PHILIP A. SCHRODT AND ÖM ÜR YIL MAZ

Index 


\section{Figures}

3.1 Frequency of intermediary interventions per year by type, 1946-2000 47

4.1 The conflict game in extensive form 72

$\begin{array}{lll}4.2 & \text { The invitation game } & 74\end{array}$

$\begin{array}{lll}4.3 & \text { The mediation game } & 77\end{array}$

6.1 Promised guarantees and types of agreement 125

8.1 A model of softening up $\quad 167$

12.1 The mediation process 266

12.2 Enhanced cultural effects model 267

13.1 Comparison of CAMEO mediation events and WEIS mediation patterns

298 


\section{Tables}

2.1 Mediator attributes

2.2 Mediation and the likelihood of an agreement mediated or negotiated conflict management efforts

2.3 The effect of mediation attributes on dichotomous outcomes

2.4a Multinomial logit analysis of mediator attributes on conflict management in high-intensity disputes

2.4b Multinomial logit analysis of mediator attributes on conflict management in low-intensity disputes

2.5 Dichotomous analyses of mediation outcomes

3.1 Frequencies of specific third-party intermediaries by type, 1946-2000

3.2 Categories of third-party intermediary interventions

3.3 The effect of third-party intermediaries on negotiated settlements

3.4 Types of third parties and management of negotiated settlements

3.5 Predicted probabilities of negotiated settlement by actor and type

4.1 Probability of winning and the likelihood of mediation, probit analysis of MIDs, 1945-1995

4.2 Mediator's credibility and intrusiveness of mediation: multinomial logit analysis of MIDs, 1945-1995

4.3 Mediator's credibility and the outcome of mediation: Heckman selection probit analysis of MIDs, 1945-1995

4.4 Mediator's credibility and mediation outcomes: multinomial logit analysis of MIDs, 1945-1995

5.1 Censored probit model of state mediation success hypothesis 1

5.2 Censored probit model of mediation success hypothesis 2

6.1 Probit estimates on promised and supplied guarantees

6.2 Requests for, and promises of, guarantees 
$\begin{array}{lll}6 \text { A.1 List of guarantees } & 130\end{array}$

7.1 Security Council peacemaking/mediation resolutions (1945-2001)

7.2 Negative binomial regression of the intensity of Security Council resolutions biased against the initiator (1946-2001)

7.3 Negative binomial regression of intensity of Security Council resolutions biased against the target (1946-2001) $\quad 150$

$\begin{array}{ll}8.1 \text { Conflict management onset } & 176\end{array}$

8.2 Marginal effects for conflict management onset 177

9.1 Power relations and mediation in international crises, 1918-2003

9.2 Logit models of the effects of mediation, mediation styles and power on formal agreements

9.3 Logit models of the effects of mediation, mediation styles and power on tension reduction

9.4 First differences in predicted probabilities of formal agreement

202

9.5 First differences in predicted probabilities of tension reduction

10A.1 Overall sample data 234

10A.2 PC sub-sample data 235

10A.3 Logit results - model 1, formal outcome (dependent variable): overall sample

10A.4 Logit results - model 1, formal outcome (dependent variable): protracted conflict sub-sample

11.1 Summary statistics for ICOW claim data 253

11.2 Third-party settlement attempts 257

$\begin{array}{ll}12.1 \text { Mediators' techniques } & 276\end{array}$

$\begin{array}{ll}12.2 & \text { A sample of community disputes } \\ 12.38\end{array}$

$\begin{array}{ll}12.3 \text { Mean use of mediation techniques } & 279\end{array}$

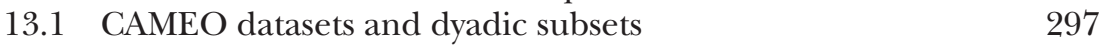




\section{Contributors}

\section{Editors}

Jacob Bercovitch is Professor of International Relations at the School of Political Science and Communication at the University of Canterbury, in Christchurch, New Zealand. He has written extensively on mediation for more than 20 years and has published papers on this subject in most of the leading journals in the field.

Scott Sigmund Gartner is Professor of Political Science at the University of California, Davis. He is author of Strategic Assessment in War and coeditor of The Historical Statistics of the United States, and has published on international politics in a variety of journals that include: The American Political Science Review, The American Sociological Review, The Journal of Politics, International Studies Quarterly and the Journal of Conflict Resolution.

\section{Contributors}

Victor Asal is Assistant Professor of Political Science at the Rockefeller College, University at Albany, SUNY. He specializes in ethnic conflict and terrorism as well as international crisis behavior and the uses of simulation and experimental approaches for research and education.

Michelle Benson is Assistant Professor in the Department of Political Science at the University at Buffalo, SUNY. She is particularly interested in researching the determinants of international and domestic conflict. More recently her work has focused on how state preferences influence international conflict and how state preferences within international governmental organizations affect their behavior. Her work has been published in the Journal of Conflict Resolution, Comparative Political Studies, the Journal of Peace Research, International Interactions, Conflict Management and Peace Science and Social Science Quarterly, among others.

David Carment is Professor of International Affairs at the Norman Paterson School of International Affairs, Carleton University, Ottawa. He is the principal investigator for the Country Indicators for Foreign Policy 
(CIFP) project. Carment's most recent work focuses on developing failed state risk assessment and early warning methodologies evaluating models of third-party intervention. He is a Fellow at the Canadian Defence and Foreign Affairs Institute and was the Director of the Centre for Security and Defence Studies at Carleton University. His recent books include Peacekeeping Intelligence: New Players, Extended Boundaries (2006).

Tsungting Chung is Associate Professor in the Department of Business Administration, National Yunlin University of Science and Technology, Yunlin, Taiwan. He is the author of a newly published book on international negotiation (in Chinese) and is currently working on investment and transaction negotiations.

Mark J.C. Crescenzi is currently Associate Professor of Political Science at the University of North Carolina. He received his PhD from the University of Illinois in 2000. He is the author of a book on economic interdependence and international conflict (Lexington, 2005) as well as journal articles in the American Journal of Political Science, the Journal of Politics, International Studies Quarterly, the Journal of Conflict Resolution and others. His work focuses on the role of reputation in the onset of militarized violence, the impact of historical conflict on future violence, the importance of the democratic community in the democratic peace and the ties between economic interdependence and political violence.

Paul F. Diehl is Henning Larsen Professor of Political Science at the University of Illinois and Director of the Correlates of War Project.

William J. Dixon is Professor and Department Head of Political Science at the University of Arizona. Professor Dixon's recent research has focused on international conflict and conflict management and on the role of domestic governing institutions on international relations. His articles have appeared in a variety of journals such as International Organization, the Journal of Conflict Resolution and American Political Science Review.

Daniel Druckman is Professor in the Department of Public and International Affairs at George Mason University and at the Australian Centre for Peace and Conflict Studies at the University of Queensland, Brisbane. He received the 2003 Lifetime Achievement Award from the International Association of Conflict Management and is currently studying the relationship between principles of justice and the durability of peace agreements.

Souleima El Achkar holds a Masters of Arts in Economics with a specialization in Econometrics from Concordia University in Montreal, and a Masters of Arts in International Affairs with a specialization in International Development from Carleton University in Ottawa. 
Derrick V. Frazier is Assistant Professor of Political Science at the University of Illinois, Urbana-Champaign. His primary research has focused on third-party mediation and conflict management. Other research interests include regional security dynamics and US foreign policy as it relates to international security.

The late Deborah J. Gerner was Professor of Political Science at the University of Kansas. Her teaching and research interests focused on the Middle East, mediation and conflict resolution. She is author of One Land, Two Peoples: The Conflict Over Palestine (Westview, 1994) and co-editor of Understanding the Contemporary Middle East (Rienner, 2004).

J. Michael Greig is Assistant Professor of Political Science at the University of North Texas. His work on conflict management has appeared in the American Journal of Political Science, International Studies Quarterly, the Journal of Conflict Resolution and the Journal of Politics. In addition to his conflict management research, he is currently studying the consequences of imposed polities in the international system.

Kelly M. Kadera is Professor of International Relations and Positive Political Theory in the Department of Political Science at the University of Iowa. She is the author of The Power-Conflict Story: A Dynamic Model of Interstate Rivalry (2001), and of a variety of articles in refereed journals, including the American Journal of Political Science, the Journal of Conflict Resolution, Conflict Management and Peace Science and International Interactions. She was the 2008 General Program Chair of the Annual Meeting of the International Studies Association and is the founder, principal investigator and co-convener of the "Journeys Workshop," an annual conference/workshop program held since 2004 to advance the career development of women in International Relations.

Zeev Maoz is Professor of Political Science at the University of California, Davis. He is the author of six books and over 75 articles on international relations, strategy and Middle East politics. His most recent book, Defending the Holy Land: A Critical Analysis of Israel's Security and Foreign Policy was published in 2006 by the University of Michigan Press.

Sara McLaughlin Mitchell is Associate Professor of Political Science at the University of Iowa, and co-Director of the Issue Correlates of War (ICOW) project (with Paul Hensel). She has published articles in leading political science journals including the American Journal of Political Science, the Journal of Politics, the Journal of Conflict Resolution and International Studies Quarterly. Her areas of expertise include international conflict, conflict management, international institutions and political methodology.

David Quinn is a PhD candidate at the University of Maryland, College Park. His research focuses on ethnic and international conflict and 
crisis, with a current concentration on self-determination movements and international crisis mediation.

Yiagadeesen Samy is Assistant Professor of International Affairs at the Norman Paterson School of International Affairs, Carleton University, Ottawa. He holds a PhD in Economics from the University of Ottawa and his current research interests include trade and labor standards, foreign direct investment, aid and debt relief and the determinants of state fragility. His work (authored and co-authored) has been published in several journals, including Applied Economics, the Journal of International Trade and Economic Development, Perspectiva Magazine, Canadian Foreign Policy and Foreign Policy Analysis.

Nil S. Satana is Assistant Professor at Bilkent University in Ankara, Turkey. She pursued her Master's and Doctoral degrees at SUNY, Buffalo from 2001-2006. Her major research interests include third-party intervention and mediation in civil and interstate conflict, as well as civil-military relations and the effect of religious fundamentalism in international relations. She is also an area expert on conflict in the Middle East, specifically on the Kurdish issue.

Burcu Savun is Assistant Professor of Political Science at the University of Pittsburgh. Her primary research focuses on conflict resolution. She has published articles in the Journal of Politics and International Studies Quarterly.

Philip A. Schrodt is Professor of Political Science at the University of Kansas. His research focuses on the development of quantitative methods for the analysis of political conflict. He has published over 80 articles in political science publications, including the American Political Science Review, American Journal of Political Science and the Journal of Conflict Resolution.

Kathleen (Young) Smarick is the Executive Director of the National Consortium for the Study of Terrorism and Responses to Terrorism (START), a US Department of Homeland Security Center of Excellence based at the University of Maryland. Previously, Smarick served as the Director of the ICONS Project international negotiation simulation program. She has a PhD from the University of Maryland's Department of Government and Politics and her research focuses on state behavior during times of crisis.

Isak Svensson, PhD, is Assistant Professor at the Department of Peace and Conflict Research at Uppsala University, Sweden. His main area of research is conflict resolution, in particular the role of mediation, mediation bias, peace agreements and religious dimensions of armed conflicts, utilizing statistical approaches. He has also done research on the Norwegian mediation efforts in Sri Lanka. He has published studies 
in the Journal of Conflict Resolution, the Journal of Peace Research, International Negotiations and Negotiation Journal.

Lesley G. Terris received her $\mathrm{PhD}$ in Political Science from Tel-Aviv University. Her research investigates international negotiation and mediation processes, while combining game-theoretic modeling with quantitative and qualitative analysis. Her research interests also include the study of international politics through simulations and network analysis.

James A. Wall is a Curators' Professor at the University of Missouri. He has served as the President of the International Association of Conflict Management and currently studies community mediation in various countries.

Jonathan Wilkenfeld is Professor of Government and Politics and Director of the Center for International Development and Conflict Management at the University of Maryland. He specializes in foreign policy, international conflict and crisis, mediation and the application of simulation and experimental approaches in international politics. His most recent books are A Study of Crisis (2000, with Michael Brecher) and Mediating International Crises (2005, with Kathleen Smarick, David Quinn and Victor Asal).

Wan Yan is a former employee of Deutsch Bank and is currently a PhD candidate at the University of Missouri.

Ömür Yilmaz received her PhD in Political Science from the University of Kansas. She is currently doing field research and working at KAMER Foundation in Diyarbakir, Turkey. Her research interests include civil conflict, social mobilization, contentious politics and gender politics. 


\section{Acknowledgments}

This book is the product of many years of work by both of us into different ways of thinking about conflict management. In its specific form, the book had its origins in a special panel we helped to set up for the American Political Science Association Annual Meeting in Washington, DC in 2005. The success of the panel encouraged us to edit a special issue of International Interactions on empirical approaches to mediation, and to expand on that theme with this book.

Edited books can often be a source of much distress and disagreement. We know very little about that. This book reflects a truly collaborative effort between us, working across the vast Pacific Ocean, and the contributors, gathered from all parts of the world. All the contributors are close friends or colleagues of ours with whom we have interacted at many meetings, worked on different projects, and for whom we have the greatest respect. That they all acceded to our demands for revisions, helped in reviewing chapters, made any changes asked of them and did all of it in good spirit, is a testament to their professionalism and experience. We are truly grateful to each and every one of you.

We are thankful to Jacek Kugler and Yi Feng, the editors of International Interactions, for encouraging us to edit a special issue of the journal devoted to the theme of empirical approaches to mediation.

Thanks are due to Andrew Humphrys and his editorial team at Routledge. They have been patient with us and never once lost faith in the project. They prodded us when prodding was necessary, but they did it ever so judiciously and kindly, We doubt we even realized we were being cajoled or pressured.

We have both been supported by the universities at which we teach and work, Canterbury and Davis. We received research support from our respective offices, and we were able to meet several times, without once straining the relations between us, at various locations in New Zealand and the US.

We would like to thank a number of individuals at Canterbury and Davis for their help. People such as Jud Fretter, Terry Genet, Jill Dobly and Molly Mellin deserve special and very public thanks.

We dedicate this book to those most in need of knowledge about effective conflict management in the world today: our young daughters. 


\title{
1 New approaches, methods and findings in the study of mediation
}

\author{
Jacob Bercovitch and Scott Sigmund Gartner
}

One of the central issues in the study of the mediation of international conflicts and crises, and indeed in many other aspects of the social sciences, is how best to explain variance? Why do seemingly similar efforts produce such markedly different outcomes? The usual temptation is to fall back on idiosyncratic factors and explain observed variance with reference to personalities, unique circumstances, personal and perceptual factors and other exceptional conditions. The central argument of this book is that such efforts paint an incomplete picture of the conflict management process, and we do, in truth, have to explore variance in a much more systematic manner. If we are to understand why some patterns of conflict management work, or are effective, and others are not, we have to operate within an explicit theoretical framework, adopt systematic empirical approaches (and there is a vast array of such approaches) and use a diversity of methods to identify critical interactions, contexts and relationships. Ideally, we would pursue these multiple objectives by also employing state-of-the-art methods and techniques. This is what we propose to do in the chapters of this book.

Let us first start by looking at two major instances of international mediation that have produced different results despite many similar features. In September 1978, American President Carter invited President Sadat of Egypt and Prime Minister Begin of Israel to his retreat at Camp David. Closeted there for 13 days, Carter tirelessly mediated the issues in dispute that had led to a number of costly conflicts and was largely instrumental in achieving a formal peace agreement between Israel and Egypt that has lasted almost 20 years. In July 2000, US President Clinton invited the President of the Palestinian Authority, Yasir Arafat, and the Prime Minister of Israel, Ehud Barak, to Camp David to hammer out an agreement between these two bitter enemies. Despite Clinton's equally tireless work, his mediation efforts failed. Clearly the issues, personalities and international climate between the cases were quite different. However, can we go beyond a description of each case and understand how Carter's and Clinton's experiences differed systematically? Can we identify which factors and variables produced each outcome and how a change in some 


\section{J. Bercovitch and S.S. Gartner}

variables might have led to different results? How do we, in short, understand the bigger picture of mediation, generate insights into the factors that account for its variance and learn how to change some of these factors so as to maximize the chances of success?

To answer these questions we want to suggest that it is possible to draw on three very different types of conflict management literatures: prescriptive, normative and descriptive (Bell et al., 1989).

Prescriptive theories of conflict management, negotiation and mediation explain any variance by emphasizing a set of behavioral norms that parties in conflict either follow (and hence achieve success), or fail to follow (and hence experience failure). Fisher and Ury (1981) provide us with a typical example of the prescriptive approach to conflict management. They offer some strategies of behavior, which if adopted by parties in conflict, irrespective of size, context or issues, lead to success. Failure to adopt these will lead to a bad outcome. The problems of explaining variance in outcomes are thus taken care of, but in a most unconvincing fashion.

Normative theories suggest how ideal, rational actors with all the information at their disposal and coherent personality structures should make decisions in complex situations (Kydd, 2003, 2005; Rauchhaus, 2006). Normative theories, best exemplified by formal models and game theoretic approaches, purport to explain the motivation and behavior of actors in conflict on the basis of some assumptions regarding rationality, information and direct causal links to any choice of strategy. Normative theories have coherence, logic and consistency, but the assumptions on which they are based clearly restrict their applicability. Actors in conflict do not behave like intelligent and sensitive parties, they do not have much information (indeed the conflict may be over lack of information), and it is hard to see how this approach, extensive though its contributions are, can be as congruent with reality as we would wish it to be.

Descriptive (though a better term for these would be empirical) theories purport to explain how and why actors behave the way they do without, in any way, trying to modify, idealize or moralize such behavior. Here, conflict behavior such as mediation or negotiation is treated as a factor that is dependent on a number of antecedent dimensions that are both observable and theoretically significant, and whose specific interaction in a given context produces success or failure. Our main focus is with conflict management behavior in the form of mediation. We wish to suggest that observed variance in the success or effectiveness of mediation has to do with many independent, contextual and specific dimensions, all of which we can observe, many of which we can evaluate, and each of which may help to explain success or failure.

Each of these three broad theories can help us gain a better understanding of the processes involved in conflict resolution, and each is evaluated along different dimensions. Prescriptive theories are evaluated by 
their pragmatic ability to help real actors in conflict make better choices and better decisions. Normative theories are evaluated by their internal consistency, logic and ability to explain multiple phenomena with one theoretical process. Descriptive or empirical theories are evaluated by degree of correspondence with observed reality and ability to produce generalizable conclusions (see Druckman, 2005). It is with this set of broad theories that we wish to proceed here.

For many years there was a strong tendency to study conflict management in general and mediation in particular with a prescriptive framework. Recently, there has been more work employing the normative approach. The main focus of the chapters in this book, however, is on presenting empirical studies on mediation and assessing their usefulness and relevance. In particular, we think that empirical studies can provide useful information on the place, role, performance, effectiveness and selection of mediation in international relations. We present empirical studies of the sort below, contribute to our understanding of effective mediation and to our ability to generate practical guidelines for policy-makers.

To start with, there are a number of ways to pursue empirical research on conflict management and mediation - and each has strengths and weaknesses. Some of the more prominent avenues of research are: single case studies; experimental approaches; and systematic, large-N studies. Case studies (e.g. Ott, 1972; Mitchell and Webb, 1988) offer detailed and often considerable insights into a particular conflict, but the emphasis on the uniqueness of each case clearly undermines any attempt to offer generalizations or look for broad patterns. Experimental approaches (e.g. Rubin, 1980; Carnevale and De Preu, 2005; Pruitt, 2005) provide for complete control of the environment and the ability to test hypotheses on motivation, preferences and behavior (strong internal validity). However, the extent to which it is possible to extrapolate from the simulated and fully scripted world of naïve subjects to the real world of diplomacy and policy-makers is very doubtful indeed (weak external validity). Systematic, large-scale studies purport to describe and explain real international events by using explicit criteria and definitions, a large and replicable dataset and sophisticated social science methods that help us to identify key relationships, connections and patterns that may affect mediation outcomes. Such studies have their own problems (e.g. the reliance on survey research and archival material that may not always be congruent with "reality"). However, given the need to examine social processes systematically and offer evidence and findings that can be looked at by others, we believe that the empirical approaches we present here are at the cuttingedge in the evolution of research on conflict management. Empirical approaches to mediation, whether case studies, large-N studies or formal models, generate new knowledge and confirm patterns, and by supporting conditional theoretical arguments, provide policy guidelines for more effective conflict management (Bercovitch, 2005). 


\section{J. Bercovitch and S.S. Gartner}

Equally important, empirical approaches have been generally underutilized in the study of conflict management. Other areas of international relations embraced such approaches with greater alacrity then did scholars of conflict management. When one thinks of just how far the democratic theory ideas have evolved, and how closely we have come to formulating a basic law on democracy and external behavior in comparative government, we can only bemoan the paucity of similar efforts in the study of mediation. Hence, the chapters below attempt to redress this imbalance and show the emerging strength, vibrancy and relevance of the empirical approach for understanding conflict management in general and mediation in particular.

\section{On conflict management and mediation}

Conflict is, without doubt, one of the most pervasive and costly of all social processes. It represents the systematic and organized employment of force and violence. Conflict's human losses represent the most salient type of political cost (Gartner, 2008; Gartner et al., 2004). Conflict's adverse consequences can be particularly dangerous in the international environment where the very existence of political actors may be threatened. Hence the importance attached to conflict management. Conflict management is an attempt to do something about reducing, limiting or eliminating the level, scope and intensity of violence in conflict, and to build a structure where the need to resort to violence in future conflicts is controlled (Deutsch, 1973; Maoz, 2004). Conflict management takes on various forms. It can be unilateral, where one party simply avoids conflicts or withdraws from any emerging conflict or it can be bilateral and involve the disputants in direct or tacit negotiations. Conflict management can also be multilateral, where an outside party, organization or state intervene peacefully to help the adversaries with their conflict management efforts. While conflict can be largely a coercive interaction, conflict management is largely non-violent and incorporates a considerable degree of voluntary coordination and joint decision-making between the parties in conflict. Hence the importance scholars attach to understanding conflict management.

How then does mediation fit into the overall framework of conflict management? Many policy tools are available for parties in conflict. These include conflict prevention, conflict management (e.g. reaching a political settlement) and conflict resolution (e.g. resolving all outstanding issues in conflict). Some of these methods are enumerated in the Article 33 (1) of the United Nations Charter, and they range from avoidance of conflict to the use of force. Broadly speaking, we can group these into four different categories. These are: (1) the use of force and coercive measures; (2) judicial and legal processes; (3) formal and informal bilateral methods; and (4) various forms of non-coercive, third-party interven- 
tions (these may be undertaken by a host of actors). These four ways of managing conflicts correspond roughly to power-based approaches to conflict (deterrence, sanctions), rights-based approaches (appeals to legal norms), and interests-based approaches (searching for common interests through bilateral negotiation and third-party mediation). Each approach has different features, characteristics, objectives and consequences, each entails different costs and resources, and each may be appropriate for different conflicts.

The approach we wish to focus on is third-party mediation. Mediation is by far the most common form of peaceful third-party intervention in international conflicts. It is predicated on the need to supplement conflict management, not to supplant the parties' own efforts. Although mediation has become an integral part of many systems (e.g. labor-management, family disputes), it is a form of conflict management that is particularly well-suited to the international environment with its numerous and diverse political actors all interacting to achieve scarce resources or influence, and where each guards its interests and autonomy jealously and accepts any outside interference in their affairs only if it is strictly necessary and explicitly circumscribed. Mediation is both voluntary and peaceful, and this makes it an attractive option for many states.

First, then, how do we frame mediation and distinguish it from other forms of peaceful interventions? There is little consensus in the literature on how mediation, or other key variables, should be defined. Scholars from different disciplinary backgrounds offer different definitions, compounding confusion and fragmentation. We want to synthesize many aspects of the mediation literature and develop a definition that will allow us to create a contextual framework of the process. Hence, we view mediation as a form of joint decision-making in conflict in which an outsider controls some aspects of the process, or indeed the outcome, but ultimate decision-making power remains with the disputants (Moore, 1986). Mediation is best seen as an extension of bilateral conflict management. It is a rational, political, though at times risky, process with anticipated costs (e.g. time spent mediating) and benefits (e.g. achieving a reputation as a successful mediator). It operates within a system of exchange and social influence whose parameters are the actors, their communication, expectations, experience, resources, interests and the situation within which they all find themselves. Mediation is a reciprocal process; it influences, and is in turn influenced by and responsive to, the context, parties, issues, history and environment of a conflict (Beardsley, forthcoming). All these aspects shape and influence the selection, process and outcome of mediation (Gartner and Bercovitch, 2006).

A satisfactory definition of mediation has to capture the broad and comprehensive features of the process and be relevant to studies of disputes, wars, and crises, such as those included in this book. Here we define mediation as a 
process of conflict management, related to but distinct from the parties' own efforts, whereby the disputing parties or their representatives seek the assistance, or accept an offer of help from an individual, group, state or organization to change, affect or influence their perceptions or behavior, without resorting to physical force, or invoking the authority of the law.

(Bercovitch, 1992: 8)

This may be a broad definition indeed and it may encompass a wide range of activities, but we believe such a definition captures the dynamics of mediation as it changes forms and features, and encapsulates the various approaches and methodologies presented in this book. Given such a broad definition, some of the questions to which we seek answers include: how mediators initiate mediation and what considerations influence this process; how mediators behave in mediation; what types of mediators are best suited to certain disputes; which mediation strategies are more useful; how mediators relate to and interact with disputants; and how the context of a conflict affects their behavior?

In many respects mediation is as old as conflict itself. The practice of settling conflicts through a third party has a rich history in all cultures (Gulliver, 1979). In international relations, mediation is likely to be used in some, though by no means all, conflicts. It is particularly useful when a conflict has gone on for some time, when the efforts of the parties involved have reached an impasse, when neither party is prepared to countenance further costs or escalation of the dispute and when both parties are ready to engage in direct or indirect dialogue, and are prepared to accept some form of external help and surrender some control over the process of conflict management. In the current international environment mediation plays an increasingly important role, and it behooves us to have a better appreciation of it.

The book is organized so as to reflect our broad approach to mediation, highlight the dimensions that influence it, and showcase how different empirical approaches can provide us with insightful and often policy-relevant findings. The framework of the book is meant to suggest that mediation is more than just a matter of choice (rational or otherwise) between two or more parties and a mediator. It is also a framework that we believe can fruitfully join theories and measurements, methods and new findings. We see mediation as a problem-solving approach that is shaped and affected by the interaction of different dimensions. It is affected by the range of possible or available mediation strategies, by who the mediators are (e.g. personal and organizational attributes), by context, setting and nature of a dispute (e.g. intrastate or interstate, intractable or shortterm), and of course, the nature of the environment in which the dispute takes place (e.g. a structured, well-regulated environment, or an unstructured environment). These dimensions help to construct the form and 
content of mediation in any situation. They may well explain why a competitive process where parties may be committed to more conflict has been transformed into a cooperative process where the goal is to achieve some degree of mutual and acceptable consensus. What we are saying here is that if we are to understand the circumstances under which mediation occurs, how it unfolds and how, in particular, we can say something meaningful and relevant about both its effectiveness and variance in its success rate, then we have to be fully cognizant of the dimensions that affect the process and determine its rate of variance. That is precisely what we are doing here with the subsequent chapters.

\section{The chapters}

The studies in this book reflect our thinking about the importance of examining conflict management systematically, and in particular, why it is critical to undertake new, large-N studies of mediation. The authors methodically examine some of the most critical conflict management questions and attempt to address a number of vital lacunas in the dispute resolution literature. In the organization of the book, the chapters build from the micro (mediation strategy) to the macro (the global environment), creating a multi-layered approach to conflict management that addresses such topics as mediation actions, mediator type, conflict management outcome, dispute characteristics and the conflict management environment.

Rather than summarize each chapter here, we focus instead first on their key theoretical contributions and then, more briefly, we address what they offer in terms of empirical and methodological advances.

We begin with the recognition that mediators are not just bystanders they are themselves actors in the conflict management enterprise. Are mediators' actions effective? In Chapter 2, we (Jacob Bercovitch and Scott Sigmund Gartner) find that powerful international mediators (e.g. large states, the UN) who utilize active, intrusive resolution strategies and can marshal significant resources and leverage in support of their efforts are more effective at managing intense conflicts, while lower profile mediators using a more passive strategy and utilizing fewer resources do better at managing less challenging and intractable conflicts. This seems to hold true across a variety of contexts and issue types.

In Chapter 3, Derrick V. Frazier and William J. Dixon explore the effect of variation in mediation strategy and actions on conflict management outcomes. They contrast the effects of militarized interventions (e.g. peacekeeping troops) with conflict management efforts (e.g. mediation) on ending conflicts. The authors find that all conflict management efforts have a positive impact on dispute resolution, but that military intervention and third-party mediation by international and regional organizations are the most effective. 


\section{J. Bercovitch and S.S. Gartner}

There is tremendous variation in mediator type. How does the mediator's identity influence the negotiations and result of conflict management? The authors explore two important lines of research here. Mediators are neither uniform nor homogeneous. One might be close to one or both of the disputants, or have little past history with any of the dispute's participants. These relationships greatly affect perceptions of mediator bias, which in turn profoundly affects the credibility of the information the mediators provide the disputants. In Chapter 4, Zeev Maoz and Lesley G. Terris show just how important bias and credibility are for conflict management. They find that perceptions of credibility affect both the likelihood of a mediator choosing to be involved in a dispute and their probable effectiveness in resolving the conflict.

In Chapter 5, Burcu Savun thoroughly examines the role of mediator bias and information. Applying bargaining theory, she identifies the conditions under which information facilitates cooperation among the disputants. Savun shows that providing information can be an effective mediation strategy if used by mediators who have relevant information about the disputants.

Recently, one type of mediator has played an especially large role in global dispute resolution - the United Nations. Many anticipate that the importance of the UN will continue to grow. Chapter 6 by Isak Svensson and Chapter 7 by Michelle Benson and Nil S. Satana identify the importance of the UN as a mediator, both in terms of special characteristics and influence. Svensson examines arguments about requested, promised and supplied guarantees in peace agreements, with data on internal armed conflicts after the end of the Cold War. In particular, he shows that the UN has a higher level of credibility than non-UN mediators and that this credibility has a significant impact on the dynamics of civil war termination.

Benson and Satana in Chapter 7 examine the influence of UN Security Council resolutions on conflict management. They find that the likelihood of UN resolutions is not driven by the power or position of any state or group of states in the Security Council. They argue that it is critical not only to examine UN peacekeeping actions, but also conflict management resolutions that do not involve peacekeeping, in order to paint a complete picture of the role of the UN in dispute resolution.

Moving beyond the mediator to a larger context, three chapters examine how dispute and crisis characteristics influence conflict management. In Chapter 8, J. Michael Greig and Paul F. Diehl identify the characteristics that influence the effectiveness of conflict management. They argue that factors such as the cost of the conflict, diplomatic exit strategies and the dynamics of rivalry all influence the initiation of mediation. Mediation is offered and accepted only in certain conflicts; Greig and Diehl take us a long way toward understanding the pre-conditions of mediation.

Chapter 9, by David Quinn, Jonathan Wilkenfeld, Kathleen Smarick and Victor Asal, examines crises and the role that disputants' relative power plays in affecting outcomes. Surprising perhaps to some, but nicely 
predicted by the authors, power - despite being frequently identified as central to variation in the mediation process - has little independent effect on conflict management, but rather acts indirectly through mediator identity and strategy to resolve crises.

Just as all disputes are not the same, neither are all states. In Chapter 10 David Carment, Yiagadeesen Samy and Souleima El Achkar examine the influence of failed and fragile states on conflict management. Comparing the performance of directive or manipulative techniques in protracted conflict situations, relative to "softer" approaches such as facilitation, which may be part of a more integrative strategy; they find that the sequence of actions matter. They suggest viewing mediation effectiveness as the cessation of violence and the initiation of the process whereby adversaries address mutual grievances and the underlying causes of hostility.

Conflict management occurs within a historical context that can influence its nature and effectiveness. In Chapter 11 Sara McLaughlin Mitchell, Kelly M. Kadera and Mark J.C. Crescenzi explore the influence of the global community, and in particular its democraticness, on third-party conflict management. They argue that a strong democratic community facilitates the likelihood and effectiveness of third-party dispute resolution and that these third-party mediators are especially likely to be democracies or international institutions. While many examine the demand for mediation services, these authors analyze the supply of mediation. They find that a significant part of the influence of the democratic community operates through its propagation of democratic societal norms of dispute resolution.

In Chapter 12 James A. Wall, Tsungting Chung, Daniel Druckman and Wan Yan apply empirical methods in a small sample of cases to study the influence of different cultural contexts on conflict management. The difficulties of formal comparisons of distinct types of conflicts are overcome here through rigorous tests. Philippine mediators - because of differences in the power of mediation and legal systems as well as cultural norms - are more assertive than their Taiwanese counterparts. Thus, for example, Philippine mediators can dictate concessions, request forgiveness and criticize disputants more often than Taiwanese mediators. In contrast, Taiwanese conflict managers utilize more passive approaches, such as giving advice, calling for empathy and citing laws more frequently than the Philippine mediators.

Finally, Chapter 13 by Deborah J. Gerner, Philip A. Schrodt and Ömür Yilmaz introduces a new dataset - called Conflict and Mediation Event Observations (CAMEO). CAMEO is especially well suited for pursing the two central themes of this book: (1) the importance of large-N statistical analysis for analyzing conflict management; and (2) the usefulness of pursuing multiple levels of analysis, from the micro to the macro, when examining dispute resolution. By providing and discussing the CAMEO data, the authors greatly facilitate future explorations of conflict management 
that build on, and hopefully will move beyond, many of the findings reported in these chapters.

One of the strengths of the chapters in this book is that, combined, they show the vast data resources and methods available for exploring conflict management issues (for a systematic comparison of datasets see Gartner and Melin, forthcoming). Many of the datasets analyzed here are new, newly revised or represent critical contributions by the data collectors. In addition to CAMEO, discussed in Chapter 13, datasets used here include (but are not restricted to), International Conflict Management (ICM) (Bercovitch and Gartner, and Savun); Militarized Interstate Dispute (MID) and Correlates of War (Greig and Diehl); a new dataset on UN Security Council resolutions (Benson and Satana); the Issue Correlates of War (ICOW) dataset (Mitchell et al.); a new dataset on Intermediary Dispute Behavior (Frazier and Dixon); a new dataset that combines the ICM and MID data (Maoz and Terris); the Uppsala Conflict Data Base (Svensson); and the International Crisis Behavior dataset (Quinn et al. and Carment et $a l$.). In another dataset Wall et al. conduct over 100 interviews on community mediation in the Philippines and Taiwan. Most of the analyses include sophisticated combinations (merging) of multiple datasets. For example, Svensson integrates the Uppsala Conflict data with figures on peacekeeping operations drawn from both Heldt and Wallensteen (2004) and the SIPRI study on multilateral peace operations.

Methods used in the chapters of this book include multinomial logit, logistic regression, logit with splines to correct for the binary time-series cross-sectional data and formal modeling. A number of the chapters employ multiple methods - making their arguments especially compelling. For example, Maoz and Terris tie game theoretic and statistical investigation of a large number of cases together. Many of the chapters provide highly rigorous tests and critical theoretical extensions of concepts discussed in case studies. For example, Greig and Diehl analyze the prescriptive notions of "ripeness" and "stalemate" to a rigorous large-N analysis.

Taken together these studies suggest that:

1 Conflict management matters and can make a difference to the course and dynamics of a conflict. In particular, who mediates, conflict management strategy and conflict characteristics all influence conflict management processes and outcomes.

2 Mediation works effectively. However we may look at it, mediation is a helpful and often satisfying procedure that consistently shows a positive effect on conflict resolution.

3 Methods other than mediation (such as peacekeeping or other forms of intervention) may be more effective under particular conditions.

4 The level of analysis is critical. Mediators at different levels of analysis (individual, state, IGO) behave differently, are suited to different conflicts and have varied effects on the process and outcome of a conflict. 
In particular, the UN increasingly represents a critical actor in international conflict management.

5 The environment in which mediation and conflict management occur is critical.

6 It is essential that we continue to develop better and more complete databases on conflict management.

The chapters here also show that unit of observation matters. For example, looking across the studies, some factors seem to lead to contradictory results until the variation in the unit of the analysis is taken into account. For example, mediation signals a particular kind of dispute, a challenging conflict that is unlikely to end in a full agreement, while mediated militarized interstate disputes and mediated crises are more likely to end in such an agreement. The differences are that some look at the conflict management effort as the unit of analysis (Bercovitch and Gartner, and Savun), while others examine the crisis (Quinn et al. and Carment $e t a l$.) or the militarized dispute (Frazier and Dixon).

\section{Future issues and concerns}

Where do we go from here? Unlike the study of interstate conflict, with its explosion of research within the democratic peace framework, conflict management studies continue to reinvent the wheel, often starting with different definitions and talking past each other. This book attempts to address some of those concerns by raising serious fundamental questions about international mediation and approaching these from a systematic empirical perspective. We begin this journey with a strong conviction that mediation should be studied within an explicit theoretical framework, and that it is a social process that, like other social processes, is susceptible to different empirical analyses. We believe it is possible, indeed desirable, to define, explore, test and work with different datasets to refine our understanding of mediation. Others can explore further the results, and the arguments can be subjected to different tests. This is how we can provide new insights and discard conventional ideas. It is only by working in this empirical fashion that we can build up knowledge and ensure that knowledge is policy-relevant.

Still, there is much to do. The whole nexus of dynamics, relationships, contexts and outcomes in mediation is quite problematic. We need to know more about this nexus, and the forces that shape its outcomes. We need to appreciate that much about mediation is truly contingent; it is a relationship of reciprocal influence, it works under some circumstances, but not others. It works well at times, but fails to do so on other occasions. By detailing the circumstances where it works, the empirical approach lends itself to practical applications. Other approaches expect us to take too much on trust. 
We need to disaggregate the complexity of mediation experiences and learn cause and effect conditions. One of the best ways of approaching a contingent problem is the systematic, empirical approach of the sort adopted in this book. We cannot just assume that mediation takes place because there is a willing mediator somewhere and a conflict to be mediated. Numerous conditions have to be met before mediation happens. We want to know something about these antecedent conditions. We need to know how mediators acquire and use credibility, how it influences the chances of mediation. We need to know how different actors use different resources, and whether there are optimal strategies to deal with different kinds of conflict. We also need to investigate further the relationship between regional membership and the resort to mediation. Is mediation a more likely response to a conflict when it occurs within a certain group of likeminded states, or is it more likely to be discarded in favor of negotiation? Similarly, what are the roles and effectiveness of conflict management by regional organizations?

We need to think about the role of different aspects not usually included in mediation studies. For example, with the exception of one chapter in this volume (Maoz and Terris), economic data receive little attention. How do economic issues and resources influence the conflict management process? Do they have any effect on the acceptance and performance of mediation? The roles of dispute and conflict management time are not well understood and one can see this clearly as one statistical method under-represented here is hazard analyses.

The relationship between potential mediators and conflicts that encourage or allow mediation is still not well defined. We know in this situation that selection plays a role, but how precisely that happens in the real world is something that we need to come back to. We know a lot about what but not much about what effects. The strategic interaction of threats and other strong-arm influences attempted with the more traditional, more diplomatic, efforts remains elusive. Which mediators use which strategies or resources in which conflicts and with what effects is one of the basic questions we need to address in future studies.

There are numerous issues to be studied. As with any other field of human endeavor, the more we understand some aspects of a process, the more new questions we seem to pose. Nevertheless, we think it is important when studying mediation to look beyond the specific case study with its unique features. The chapters of this book exemplify our belief and provide encouraging results both about the effectiveness of conflict management, mediation in particular, and the efficacy of using large-N statistical approaches for examining conflict management issues. Neither of these conclusions should be taken lightly. In practice, mediation's popularity as a way of dealing with conflict grows each year, as does its applicability to different realms. Yet, mediation research is a comparatively new area of scholarly study that for too long has been poorly understood, an area where 
descriptions and exhortations far outnumber any attempts at theory building and hypothesis testing. For many years most studies on mediation were descriptions of single historical cases where any attempt to sketch patterns was viewed with immense skepticism, or they were of the prescriptive kind where a single, pre-ordained strategy was postulated as the most effective in all conflict situations (e.g. Burton, 1969; Kelman, 1979). The prevalent agnosticism toward any form of general analysis is best exemplified by the comments made by one of the most experienced labor mediators, William Simkin, who notes that "the variables [in mediation] are so many that it would be an exercise in futility to attempt to describe typical mediator behavior with respect to sequence, timing or the use or non-use of the various functions theoretically available" (Simkin, 1971: 118). The mystery and presumed uniqueness of mediation acted, for far too long, like something of a ghost that haunted the empirical study of conflict resolution.

Neither the single case descriptions nor the prescriptive approaches are able to offer reliable and replicable theoretical explanations for how mediation works, which disputes are most amenable to mediation, which strategies are most effective, or which international mediators are best adapted to deal with which conflicts. Conversely, the studies presented here address patterns and cannot speak to the specific details of individual cases. However, we cannot advance the study of mediation by predicating it on the idea that mediation is unique, divine or prescriptive. Conflict management efforts can, and indeed should, be studied systematically, just like other social processes, with research that focuses on the full range - from micro to macro - of mediation topics. Mediation's start, conduct and results form patterns that can be analyzed and identified. It is best viewed and understood as one strategy in the broader context of conflict management strategies, where parties are free to choose the strategy they believe will best serve their interests. Once we locate mediation within the overall process of conflict management, we understand that what mediators do, are permitted to do, or what they can do, is not too dissimilar to what the parties themselves do, or can do. Whether mediation succeeds or fails depends on many factors, but it is precisely these factors that we need to identify, study and evaluate. To do otherwise would be to mistake wishful thinking for reality. There is much to be done, more exciting avenues to explore and more potential significant findings to unravel. We hope the chapters of this book spur our colleagues to go on and achieve an even better understanding of the process of mediation.

\section{References}

Beardsley, Kyle (forthcoming). "Agreement without peace? International mediation and time-inconsistency problems," American Journal of Politics.

Bell, David E., Howard Raiffa and Amos Tversky (1989). "Descriptive, normative and prescriptive interactions in decision making," in David E. Bell, Howard 
Raiffa and Amos Tversky (eds.) Decision Making: Normative and Prescriptive Interactions. New York: Cambridge University Press, pp. 9-30.

Bercovitch Jacob (1992). "The structure and diversity of mediation in international relations," in Jacob Bercovitch and Jeffrey Z. Rubin (eds.) Mediation in International Relations: Multiple Approaches to Conflict Management. London and New York: Macmillan and St. Martin's Press.

Bercovitch, Jacob (2005). "Social research and the study of mediation: designing and implementing systematic archival research," International Negotiation, 9(3): $415-428$.

Burton, John (1969). Conflict and Communication: The Use of Controlled Communication in International Conflict. London: Macmillan.

Carnevale, Peter and Christian K. De Preu (2005). "Laboratory experiments on social conflict," International Negotiations, 10(1): 51-65.

Deutsch, Morton (1973). The Resolution of Conflict. New Jersey: Yale University Press.

Druckman, Daniel (2005). Doing Research: Methods of Enquiry for Conflict Analysis. London: Sage Publications.

Fisher, Roger and William Ury (1981). Getting to Yes. Boston: Houghton Mifflin.

Gartner, Scott Sigmund (2008). "Ties to the dead: connections to Iraq War and 9/11 casualties and disapproval of the President," American Sociological Review, 73(4): 690-695.

Gartner, Scott Sigmund and Jacob Bercovitch (2006). "Overcoming obstacles to peace: the contribution of mediation to short-lived settlements," International Studies Quarterly, 50: 819-840.

Gartner, Scott Sigmund and Molly M. Melin (forthcoming). "Assessing outcomes: conflict management and the durability of peace," in Jacob Bercovitch, Victor Kremenyuk and I. William Zartman (eds.) Sage Handbook on Conflict Resolution. Thousand Oaks, CA: Sage Press.

Gartner, Scott Sigmund, Gary Segura and Bethany Barratt (2004). "Casualties, positions, and senate elections in the Vietnam War," Political Research Quarterly, 53(3): 467-477.

Gulliver, Phillip H. (1979). Disputes and Negotiations: A Cross Cultural Perspective. New York: Academic Press.

Heldt, Birger and Peter Wallensteen (2004). Peacekeeping Operations: Global Patterns of Intervention and Success, 1948-2000. Stockholm: Folke Bernadotte Academy Publications.

Kelman, Herbert C. (1979). "Reduction of international conflict: An interaction approach," in William G. Austin and Stephen Worcehl (eds.) The Social Psychology of Intergroup Relations. Monterey, CA: Brooks/Cole, pp. 288-303.

Kydd, Andrew (2003). "Which side are you on? Bias, credibility, and mediation," American Journal of Political Science, 47 (4): 597-611.

Kydd, Andrew (2005). Trust and Mistrust in International Relations. Princeton: Princeton University Press.

Maoz, Zeev (2004). "Conflict management and conflict resolution: A conceptual and methodological introduction," in Zeev Maoz, Alex Mintz, T. Clifton Morgan, Glenn Palmer and Richard J. Stall (eds.) Multiple Paths to Knowledge in International Relations: Methodology in the Study of Conflict Management and Conflict Resolution. Lanham: Lexington Books, pp. 1-32.

Mitchell, Chris and Keith Webb (eds.) (1988). New Approaches to International Mediation. New York: Greenwood Press. 
Moore, Christopher W. (1986). The Mediation Process. San Francisco, CA: Jossey Bass.

Pruitt, Dean G. (2005). "Field experiments on social conflicts," International Negotiations, 10(1): 33-49.

Ott, Marvin (1972). "Mediation as a method of conflict resolution: two cases," International Organizations, 26(3): 595-618.

Rauchhaus, Robert (2006). "Asymmetric information, mediation, and conflict management,” World Politics, 58: 207-241.

Rubin, Jeffrey Z. (1980). "Experimental Approaches on third-party intervention in conflict," Psychological Bulletin, 87(3): 379-391.

Simkin, William (1971). Mediation and the Dynamics of Collective Bargaining. Washington, DC: Bureau of National Affairs. 


\section{References}

Assefa, Hiskias (1987). Mediation of Civil Wars: Approaches and Strategies. Boulder, CO: Westview Press.

Bercovitch, Jacob (1992). "The structure and diversity of mediation in international Relations," in Jacob Bercovitch and Jeffrey Z. Rubin (eds.) Mediation in International Relations. New York: St. Martin's Press, pp. 1-29.

Bercovitch, Jacob and Judith Fretter (2004). Regional Guide to International Conflict Management. Washington, DC: Congressional Quarterly.

Bercovitch, Jacob and Allison Houston (1996). "The study of international mediation: theoretical issues and empirical evidence," in Jacob Bercovitch (ed.) Resolving International Conflicts: The Theory and Practice of Mediation. Boulder, CO: Lynne Rienner, pp. 11-38. 
Bercovitch, Jacob and Allison Houston (2000). "Why do they do it like this? An analysis of the factors influencing mediation behavior in international conflicts," Journal of Conflict Resolution, 44(2): 170-202.

Bercovitch, Jacob and Jeffrey P. Langley (1993). "The nature of the dispute and the effectiveness of international mediation," Journal of Conflict Resolution, 34(4): 670-691.

Bercovitch, Jacob and Patrick M. Regan (2004). "Mediation and international conflict management," in Zeev Maoz, Alex Mintz, T. Clifton Morgan, Glenn Palmer and Richard J. Stall (eds.) Multiple Paths to Knowledge in International Relations. Lanham, MD: Lexington Books, pp. 259-272.

Bercovitch, Jacob and Gerald Schneider (2000). "Who mediates? The political economy of international conflict management," Journal of Peace Research, 37 (2): 145-165.

Bercovitch, Jacob and Richard Wells (1993). "Evaluating mediation strategies: theoretical and empirical analysis," Peace and Change, 18(1): 3-25.

Carnevale, Peter (1986). "Strategic choice in mediation," Negotiation Journal, 2(1): 41-56.

Crocker, Chester, Fen Osler Hampson and Pamela R. Aall (2004). Taming Intractable Conflicts. Washington, DC: United States Institute of Peace Press.

Diehl, Paul (2003). "Regional conflict management: strategies, necessary conditions and comparative effectiveness," in Paul Diehl and Joseph Lepgold (eds.) Regional Conflict Management. Lanham: Rowman and Littlefeld, pp. 41-79.

Fisher, Ronald (1997). Interactive Conflict Resolution. New York: Syracuse University Press.

Gartner, Scott Sigmund and Jacob Bercovitch (2006). "Overcoming obstacles to peace: the contribution of mediation to short-lived conflict settlements," International Studies Quarterly, 50(4): 819-840.

Gartner, Scott Sigmund and Patrick M. Regan (1996). "Threat and repression: the non-linear relationship between government and opposition violence," Journal of Peace Research, 33(3): 273-288.

Gartner, Scott Sigmund and Gary M. Segura (1998). "War, casualties and public opinion," The Journal of Conflict Resolution, 42(3): 278-300.

Gartner, Scott Sigmund and Gary M. Segura (2000). "Race, opinion, and casualties in the Vietnam War," The Journal of Politics, 62(1): 115-146.

Gartner, Scott, Gary Segura and Bethany Barratt (2004). "Casualties, positions, and senate elections in the Vietnam War," Political Research Quarterly, 53(3): 467-477.

Gerner, Deborah J. and Philip A. Schrodt (2001). "Analyzing the dynamics of international mediation processes in the Middle East and the former Yugoslavia," presented at the International Studies Association Meeting, Chicago, Illinois.

Greig, J. Michael (2005). "Stepping into the fray: when do mediators mediate?" American Journal of Political Science, 49(2): 249-266.

Hiltrop, Jean-Marie (1985). "Mediator behavior and the settlement of collective bargaining disputes," Journal of Social Issues, 41(2): 83-99.

Kleiboer, Marieke (1996). "Understanding success and failure of international mediation," Journal of Conflict Resolution, 40(2): 360-389.

Kleiboer, Marieke (1998). The Multiple Realities of International Mediation. Boulder, CO: Lynne Rienner.

Kochan, Thomas A. and Tom Jick (1978). "The public sector mediation process: a theory and empirical examination," Journal of Conflict Resolution, 22(2): 209-240. 
Latour, Stephen (1976). "Some determinants of preference for modes of conflict resolution," Journal of Conflict Resolution, 20(4): 319-356.

Leng, Russel (2000). Bargaining and Learning in Recurring Crises. Ann Arbor: University of Michigan Press.

Low, Stephen (1985). "The Zimbabwe settlement: 1976-1979," in I. William Zartman and Saadia Touval (eds.) International Mediation Theory and Practice. Boulder, CO: Westview Press, pp. 91-109.

Mitchell, Chris R. (1995). "The right moment: notes on models of ripeness,“ Paradigms, 9(1): 35-52.

Princen, Thomas (1992). Intermediaries in International Conflict. Princeton: Princeton University Press.

Pruitt, Dean and Kenneth Kressel (1989). Mediation Research: The Process and Effectiveness of Third Party Intervention. San Francisco: Jossey Bass.

Raven, Bert H. (1990). "Political applications of the psychology of interpersonal influence and social power," Political Psychology, 11 (4): 493-520.

Reed, William (2002). "Selection effects \& world politics research," International Interactions, 28(1): 1-3.

Rubin, Jeffrey Z. (1980). "Experimental research on third party intervention in conflict," Psychological Bulletin, 87(4): 379-391.

Sheppard, Bill H. (1984). "Third party conflict intervention: a procedural framework,” Research in Organizational Behavior, 6: 141-190.

Sherman, Frank L. (1994). "Sherfacs: a cross-paradigm, hierarchical and contextually sensitive conflict management data set," International Interactions, 20(1-2): 79-100.

Terris, Lesley and Zeev Maoz (2005). "Rational mediation: a theory and a test," Journal of Peace Research, 42(5): 563-583.

Wall, James A., John B. Stark and Rhetta L. Standifer (2001). "Mediation: a current review and theory development," Journal of Conflict Resolution, 45(3): 693-705.

Wilkenfeld, Jonathan, Kathleen Young, Victor Asal and David Quinn (2003). "Mediating international crises: cross national and experimental perspectives," Journal of Conflict Resolution, 47(3): 279-301.

Zartman, I. William and Saadia Touval (1996). "International mediation in the post Cold War era," in Chester Crocker, Fen Osler Hampson and Pamela R. Aall (eds.) Managing Global Crises. Washington, DC: USIP Press, pp. 445-462.

Zubek, Josephine, Dean G. Pruitt, Robert S. Peirce, Neil B. McGillicuddy and Helena Syna (1992). "Disputant and mediation behavior affecting short term success in mediation," Journal of Conflict Resolution, 36(3): 546-572. 


\section{References}

Abbott, Kenneth and Duncan Snidal (1998). "Why states act through formal international organizations," Journal of Conflict Resolution, 42: 3-32.

Azar, E.E. (1980). "The conflict and peace data bank (COPDAB) project," Journal of Conflict Resolution, 24: 143-152.

Bercovitch, Jacob (1984). Social Conflicts and Third Parties: Strategies of Conflict Resolution. Boulder, CO: Westview Press.

Bercovitch, Jacob (1986). "International mediation: a study of incidence, strategies and conditions of successful outcomes," Cooperation and Conflict, 21: 155-168.

Bercovitch, Jacob and Ole Elgstrom (2001). "Culture and international mediation: exploring theoretical and empirical linkages," International Negotiation, 6: 3-23.

Bercovitch, J. and A. Houston (1993). "Influence of mediator characteristics and behavior on the success of mediation in international relations," International Journal of Conflict Management, 4: 297-321

Bercovitch, Jacob and Jeffrey Langley (1993). "The nature of the dispute and the effectiveness of international mediation," Journal of Conflict Resolution, 37: $670-691$.

Bercovitch, Jacob and Gerald Scheider (2000). "Who mediates? the political economy of international conflict management," Journal of Peace Research, 37: 145-165.

Bercovitch, Jacob, J. Theodore Anagnoson and Donnette L. Wille (1991). "Some conceptual issues and empirical trends in the study of successful mediation in international relations," Journal of Peace Research, 28: 7-17.

Bratt, Duane (1996). "Assessing the success of UN peacekeeping operations," International Peacekeeping, 3: 65-81.

Butterworth, Robert (1978). "Do Conflict managers matter? an empirical assessment of interstate security disputes and resolution efforts, 1945-1974," International Studies Quarterly, 22: 195-214.

Cot, J.P. (1972). International Conciliation. London: Europa.

Diehl, Paul F. (1993). International Peacekeeping. Baltimore, MD: Johns Hopkins University Press.

Diehl, Paul F., Jennifer Reifschneider and Paul R. Hensel (1996). "UN intervention and recurring conflict," International Organization, 50: 683-700.

Dixon, William J. (1996). "Third-party techniques for preventing conflict escalation and promoting peaceful settlement," International Organization, 50: 653-681. 
Dixon, William J. and Paul Senese (2002). "Democracies, disputes and negotiated settlements," Journal of Conflict Resolution, 46: 547-571.

Fortmann, Michel, Pierre Martin and Stephane Roussel (1998). "Trial by fire: international actors and organizations in the Yugoslav crisis," in David Carment and Patrick James (eds.) The International Politics of Ethnic Conflict: Prevention and Peacekeeping. Columbia, SC: University of South Carolina Press, pp. 126-159.

Fortna, Virginia Page (2004). "Interstate peacekeeping: causal mechanisms and empirical effects," World Politics, 56: 481-519.

Frei, Daniel (1976). "Conditions affecting the effectiveness of international mediation," Papers of the Peace Science Society International, 26: 67-84.

Gerner, D.J., P. Schrodt, R.A. Francisco and J.L. Weddle (1994). "Machine coding of event data using regional and international sources," International Studies Quarterly, 38: 91-119.

Goldstein, J.S. (1992). "A conflict and cooperation scale for WEIS events," Journal of Conflict Resolution, 36: 369-385.

Gulick, Edward (1967). Europe's Classical Balance of Power. New York: W.W. Norton.

Haas, Ernest, Robert L. Butterworth and Joseph S. Nye (1972). Conflict Management by International Organizations. Morristown, NJ: General Learning Press.

Johansen, Robert C. (1994). "UN peacekeeping: how should we measure success?" Mershon International Studies Review, 38: 307-310.

Jones, D., S. Bremer and J.D. Singer (1996). "Militarized interstate disputes, 1816-1992: rationale, coding rules, and empirical patterns," Conflict Management and Peace Science, 15: 163-213.

King, Gary and W. Lowe (2003). "An automated information extraction tool for international conflict data with performance as good as human coders: a rare events evaluation design," International Organization, 57: 617-642.

Kleiboer, Marieke (1996). "Understanding success and failure of international mediation," Journal of Conflict Resolution, 40: 360-389.

Lamborn, Alan (1998). "Theoretical and historical perspectives on collective security: the intellectual roots of contemporary debates about collective conflict management," in Joseph Lepgold and Thomas Weiss (eds.) Collective Conflict Management and Changing World Politics. New York: State University of New York Press, pp. 31-56.

Laylin, J. (1972). Guidelines for Third Parties in International Disputes. Paper read at 66th Annual Meeting of the American Society of International Law.

Lepgold, Joseph and Thomas Weiss (eds.) (1998). Collective Conflict Management and Changing World Politics, SUNY Series in Global Politics. Albany: State University of New York Press.

Mearsheimer, John (1994). "The false promise of institutions," International Security, 19: 5-49.

Modelski, George (1964). "International settlement of internal war," in J. Rosenau (ed.) International Aspects of Civil Strife. Princeton: Princeton University Press, pp. 122-153.

Northedge, F.S. and M.D. Donelan (1971). International Disputes: The Political Aspects. London: Europa.

Ott, M. (1972). "Mediation as a method of conflict resolution: two cases," International Organization, 26: 595-618. 
Raymond, Gregory and Charles Kegley (1985). "Third party mediation and international norms: a test of two models," Conflict Management and Peace Science, 9: 33-52.

Regan, Patrick J. and Alan Stam (2000). "In the nick of time: conflict management, mediation timing, and the duration of interstate disputes," International Studies Quarterly, 44: 239-260.

Richmond, Oliver P. (2002). Maintaining Order, Making Peace. New York: Palgrave.

Simkin, W. (1971). Mediation and the Dynamics of Collective Bargaining. Washington, DC: Bureau of National Affairs.

Skjelsbaek, Kjell (1986). "Peaceful settlement of disputes by the United Nations and other intergovernmental bodies," Cooperation and Conflict, 21: 139-154.

Slim, Randa (1992). "Small-state mediation in international relations: the Algerian mediation of the Iranian hostage crisis," in Jeffrey Rubin and Jacob Bercovitch (eds.) Mediation in International Relations: Multiple Approaches to Conflict Management. New York: St. Martin's Press, pp. 206-231.

Steiner, H. (1940). Principles and Problems of International Relations. New York: Harper and Brothers.

Touval, Saadia (1992). "The superpowers as mediators," in Jeffrey Rubin and Jacob Bercovitch (eds.) Mediation in International Relations: Multiple Approaches to Conflict Management. New York: St. Martin's Press, pp. 232-247.

Touval, Saadia and I. William Zartman (1985). International Mediation in Theory and Practice. Boulder, CO: Westview Press.

Trachtman, Joel (1997). "The theory of the firm and the theory of the international economic organization: toward comparative institutional analysis," Northwestern Journal of International Law and Business, 17: 470-555.

Vincent, J.E. (1983). "WEIS vs. COPDAB: correspondence problems," International Studies Quarterly, 27: 161-168.

Wilkenfeld, Jonathan and Michael Brecher (1984). "International crises, 1945-1975: the UN dimension,” International Studies Quarterly, 28: 45-68.

Yarrow, C.H. (1978). Quaker Experiences in International Conciliation. New Haven, CT: Yale University Press.

Young, Oran (1972). The Intermediaries: Third Parties in International Crises. Princeton: Princeton University Press. 


\section{References}

Barbieri, Katherine, Omar Keshk and Brian Pollins (2004). BKP Trade Data Codebook. Online, available at: http://psweb.sbs.ohio-state.edu/faculty/bpollins/ data/bkp_trade_0.9_readme.pdf.

Bercovitch, Jacob (1986). "International mediation: a study of incidence, strategies and conditions of successful outcomes," Cooperation and Conflict, 21 (3): 155-168.

Bercovitch, Jacob (1992). "The structure and diversity of mediation in international relations," in Jacob Bercovitch and Jeffrey Rubin (eds.) Mediation in International Relations. London: Macmillan Press.

Bercovitch, Jacob (1999). International Conflict Management Dataset. University of Canterbury. Online, available at: www.posc.canterbury.ac.nz/jbercovitch/ mediation.html.

Bercovitch, Jacob and Patrick Regan (2004). "Mediation and international conflict management: a review and analysis," in Zeev Maoz, Alex Mintz, T. Clifton Morgan, Glenn Palmer and Richard J. Stoll (eds.) Multiple Paths to Knowledge in International Relations: Methodology in the Study of Conflict Management and Conflict Resolution. Lanham, MD: Lexington Books, pp. 249-272.

Bercovitch, Jacob, Theodore Anagnoson and Donnette Wille (1991). "Some conceptual issues and empirical trends in the study of successful mediation in international relations," Journal of Peace Research, 28(1): 7-17.

Brecher, Michael and Jonathan Wilkenfeld (1997). A Study of Crisis. Ann Arbor: University of Michigan Press.

Bremer, Stuart (1992). "Dangerous dyads: conditions affecting the likelihood of interstate war, 1816-1965," Journal of Conflict Resolution, 36(1): 309-341.

Brockner, Joel and Jeffery Z. Rubin (1985). Entrapment in Escalating Conflicts: A Social Psychological Analysis. New York: Springer Verlag.

Dixon, William (1993). "Democracy and the management of international conflict," Journal of Conflict Resolution, 37(1): 42-68.

Dixon, William (1994). "Democracy and the peaceful settlement of international conflict," American Political Science Review, 88(1): 14-32.

Dixon, William (1996). "Third Party Techniques for Prevention Conflict Escalation and Promoting Peaceful Settlement," International Organization, 50(4): 653-681.

Fearon, James D. (1995). "Rationalist explanations for war," International Organization 49(3): 379-414.

Fudenberg, Drew and Jean Tirole (1991). Game Theory. Cambridge, MA: MIT Press.

Greig, Michael (2005). "Stepping into the fray: when do mediators mediate?" American Journal of Political Science, 49(2): 249-266.

Kressel, K. and D.G. Pruitt (eds.) (1989). Mediation Research: The Process and Effectiveness of Third Party Intervention. San Francisco: Jossey-Bass.

Kydd, Andrew (2003). "Which side are you on? bias, credibility and mediation," American Journal of Political Science, 47(4): 579-611.

Leeds, Brett Ashley (2005). Alliance Treaty Obligations and Provisions Dataset. Rice University. Online, available at: www.ruf.rice.edu/ leeds.

Maoz, Zeev (1990). Paradoxes of War: On the Art of National Self-Entrapment. Boston: Unwin Hymann.

Maoz, Zeev (1998). "Realist and cultural Critiques of the democratic peace: a theoretical and empirical reassessment," International Interactions, 24(1): 3-89. 
Maoz, Zeev (2005). Dyadic MID dataset (version 2.0). University of California, Davis. Online, available at: http://psfaculty.ucdavis.edu/zmaoz/dyadmid.html.

Maoz, Zeev (2006). "Systemic polarization, interdependence, and international conflict, 1816-2002," Journal of Peace Research 43(4): 391-411.

Maoz, Zeev (2009). "The effects of strategic and economic interdependence on international conflict across levels of analysis," American Journal of Political Science, 53(1) (forthcoming, January).

Maoz, Zeev and Bruce Russett (1993). "Normative and structural causes of democratic peace, 1946-1986," American Political Science Review, 87(3): 624-638.

Morgan, Clifton (1994). Untying the Knot of War, Ann Arbor: University of Michigan Press.

Northedge, F. and M. Donelan (1971). International Disputes: The Political Aspects. London: Europa Publications.

O'Neill, Barry (1986). "International escalation and the dollar auction," Journal of Conflict Resolution, 30(1): 33-50.

Powell, Robert (1999). In the Shadow of Power: States and Strategies in International Politics. Princeton: Princeton University Press.

Powell, Robert (2004). "Bargaining and Learning while Fighting," American Journal of Political Science, 48(2): 344-361.

Princen, Thomas (1992). Intermediaries in International Conflict. Princeton: Princeton University Press.

Quandt, William B. (1977). A Decade of Decisions. Berkeley, CA: University of California Press.

Quandt, William B. (1986). Camp David: Peacekeeping and Politics. Washington, DC: Brookings Institute.

Rubinstein, Ariel (1982). "Perfect equilibrium in a bargaining model," Econometrica, 50(1): 97-109.

Singer, J. David (1987). "Reconstructing the Correlates of War dataset on material capabilities of states, 1816-1985," International Interactions, 14: 115-132.

Stevens, Carl M. (1963). Strategy and Collective Bargaining Negotiation. New York: McGraw-Hill.

Terris, Lesley and Zeev Maoz (2005). "Rational mediation: a theory and a test," Journal of Peace Research, 42(5): 563-583.

Touval, Saadia (1982). The Peace Brokers: Mediators in the Arab-Israeli Conflict, 1948-1979. Princeton: Princeton University Press.

Touval, Saadia and I. William Zartman (1985). "International mediation: conflict resolution and power politics," Journal of Social Issues, 41: 27-45.

Wall, James A. Jr., John B. Stark and Rhetta L. Standifer (2001). "Mediation: a current review and theory development," Journal of Conflict Resolution, 45(3): 370-391.

Young, Oran (1967). The Intermediaries: Third Parties in International Crises. Princeton: Princeton University Press. 


\section{References}

Abbott, Kenneth W. and Duncan Snidal (1998) "Why states act through formal international organizations," Journal of Conflict Resolution, 42: 3-32.

Achen, Christopher H. (1986) The Statistical Analysis of Quasi-experiments. Berkeley, CA: University of California Press.

Bercovitch, Jacob (1996) "The study of international mediation: theoretical issues and empirical evidence," in Jacob Bercovitch (ed.) Resolving International Conflicts: The Theory and Practice of Mediation. Boulder, CO: Lynne Rienner.

Bercovitch, Jacob (1999) International Conflict Management dataset.

Bercovitch, Jacob and Allison Houston (2000) "Why do they do it like this? The analysis of the factors influencing mediation behavior in international conflicts," Journal of Conflict Resolution, 44: 170-202.

Bercovitch, Jacob and Gerald Schneider (2000) "Who mediates? The political economy of international conflict management," Journal of Peace Research, 37: 145-165.

Carnevale, Peter J. and Sharon Arad (1996) "Bias and impartiality in international mediation," in Jacob Bercovitch (ed.) Resolving International Conflicts: The Theory and Practice of Mediation. Boulder, CO: Lynne Rienner.

Dixon, William J. (1994) "Democracy and the peaceful settlement of international conflict," American Political Science Review, 88: 14-32.

Dixon, William J. (1996) "Third-party techniques for preventing conflict escalation and promoting peaceful settlement," International Organization, 50: 653-681. 
Dorn, A. Walter (2001) "United Nations: information-gathering for peace and security," in Peter I. Hajnal (ed.) International Information, Volume 2: Documents, Publications, and Electronic Information of International Organizations. Englewood, CO: Libraries Unlimited Inc.

Europa World Year Book (1965-1996). London: Europa Publications Limited.

Fearon, James (1995) "Rationalist explanations for war," International Organization, 39: 379-414.

Fisher, Ronald J. (1972) "Third party consultation: a method for the study and resolution of conflict," Journal of Conflict Resolution, 16: 67-94.

Fisher, Ronald J. (1995) "Pacific impartial third-party intervention in international conflict: a review and an analysis," in John A. Vasquez, James T. Johnson, Sanford Jaffe and Linda Stamato (eds.) Beyond Confrontation: Learning Conflict Resolution in the Post-Cold War Era. Ann Arbor: University of Michigan Press.

Gaddis, John L. (1988) "The intelligence revolution's impact on postwar diplomacy," in Walter T. Hitchcock (ed.) The Intelligence Revolution: A Historical Perspective. Washington, DC: US Air Force Academy.

Greene, William (1996) Econometric Analysis. Upper Saddle River, NJ: Prentice-Hall.

International Institute for Strategic Studies (1965-1995) Military Balance. London: Oxford University Press.

Keohane, Robert O. (1982) "The Demand for International Regimes," International Organization, 36: 325-355.

Keohane, Robert O. (1984) After Hegemony: Cooperation and Discord in the World Political Economy. Princeton: Princeton University Press.

Keohane, Robert O. and Joseph Nye (1974) "Transgovernmental relations and world politics," World Politics, 27: 39-62.

King, Gary and Langche Zeng (2001) "Logistic regression in rare events data," Political Analysis, 9: 137-163.

Kydd, Andrew (2003) "Which side are you on? Bias, credibility, and mediation," American Journal of Political Science, 47: 597-611.

Lake, David A. and Donald Rothchild (1998) "Spreading fear: the genesis of transnational ethnic conflict," in David A. Lake and Donald Rothchild (eds.) The International Spread of Ethnic Conflict: Fear, Diffusion, and Escalation. Princeton: Princeton University Press.

Leeds, Brett Ashley and Sezi Anac (2005) "Alliance institutionalization and alliance performance," International Interactions, 31: 183-202.

Lemke, Douglas and William Reed (2001) "The relevance of politically relevant dyads," Journal of Conflict Resolution, 45: 126-143.

Marshall, Monty G. and Keith Jaggers (2002) Polity IV Project: Dataset User's Manual. College Park, MD: University of Maryland Press.

Meek, Curtis (2000) "Third party military intervention and the duration of civil wars," paper presented at the Annual Meeting of the American Political Science Association, Washington, DC.

Morgan, Clifton T. (1994) Untying the Knot of War. Ann Arbor: University of Michigan Press.

Mousseau, Michael (1998) "Democracy and compromise in militarized interstate conflicts, 1816-1992," Journal of Conflict Resolution, 42: 210-230.

Reed, William (2000) "A unified statistical model of conflict onset and escalation," American Journal of Political Science, 44: 84-93. 


\section{B. Savun}

Russett, Bruce and John Oneal (2001) Triangulating Peace: Democracy, Interdependence, and International Organizations. New York: W.W. Norton.

Savun, Burcu (2008) "Information, bias, and mediation success," International Studies Quarterly, 52: 25-47.

Signorino, Curtis S. (1999) "Strategic interaction and the statistical analysis of international conflict," American Political Science Review, 93: 279-298.

Small, Melvin and J. David Singer (1982) Resort to Arms: International and Civil Wars, 1816-1980. Beverly Hills, CA: Sage.

Smith, Alastair (1996) "To intervene or not to intervene: a biased decision," Journal of Conflict Resolution, 40: 16-40.

Smith, Alastair (1999) "Testing theories of strategic choice: the example of crisis escalation," American Journal of Political Science, 43: 1254-1283.

Smith, Alastair and Allan Stam (2003) "Mediation and peacekeeping in a random walk model of civil and interstate war," International Studies Review, 5: 115-135.

Smith, William P. (1985) "Effectiveness of biased mediator," Negotiation Journal, 1: 363-372.

Stulberg, Joseph B. (1987) Taking Charge: Managing Conflict. Lexington, MA: Lexington Books.

Young, Oran R. (1967) Intermediaries: Third Parties in International Crises. Princeton: Princeton University Press. 


\section{References}

Addison, Tony and Mansoob S. Murshed (2002). "Credibility and reputation in peacemaking," Journal of Peace Research, 39(4): 487-501.

Alt, James E., Calvert L. Randall and Brian D. Humes (1988). "Reputation and hegemonic stability: a game-theoretic analysis," American Political Science Review, 82(2).

Annan, Kofi (2005). "In larger freedom: towards development, security and human rights for all," Report of the Secretary General. A/59/2005.

Beardsley, Kyle (2006). "Politics by means other than war: understanding international mediation," dissertation, University of California, San Diego.

Bellamy, Alex J. and Paul D. Williams (2005). "Who's keeping the peace? Regionalization and contemporary peace operations," International Security, 29(4): 157-195. 
Burg, Steven L. and Paul S. Shoup (1999). The War in Bosnia-Hercegovina. Armonk, NY: M.E. Sharpe.

Dallaire, Roméo (2003). Shake Hands with the Devil: The Failure of Humanity in Rwanda. London: Arrow Books.

Diehl, Paul F. (1993). "Institutional alternatives to traditional U.N. peacekeeping: an assessment of regional and multinational options," Armed Forces E Society, 19(2): 209-230.

Dorn, Walter (1998). "Regional peacekeeping is not the way," Peacekeeping Eै International Relations, 27(3/4).

Dwan, Renata and Sharon Wiharta (2005). "Multilateral peace missions: challenges of peace-building," SIPRI Yearbook 2005: Armaments, Disarmament and International Security. Stockholm International Peace Research Institute. Oxford and New York: Oxford University Press.

Eriksson, Mikael and Stina Högbladh (2004). "Definitions of the Database Variables," in Mikael Eriksson, States in Armed Conflict 2002. The Department of Peace and Conflict Research, Uppsala, Research Report 67.

Fearon, James D. (1994). "Domestic political audiences and the escalation of international disputes," American Political Science Review, 88(3): 577-592.

Fearon, James D. (1995). "Rationalist explanations for war," International Organization, 49(3): 379-414.

Fearon, James D. (1998). "Commitment problems and the spread of ethnic conflict," in Lake, David A. and Rothchild, Donald (eds.) The International Spread of Ethnic Conflict. Princeton: Princeton University Press, pp. 107-126.

Fortna, Virgina Page (2004a). Peace Time: Cease-Fire Agreements and the Durability of Peace. Princeton and Oxford: Princeton University Press.

Fortna, Virginia Page (2004b). "Does peacekeeping keep peace? International intervention and the duration of peace after civil war," International Studies Quarterly, 48(2): 269-292.

Gilady, Lilach and Bruce M. Russett (2002). "Peacemaking and conflict resolution," in Walter Carlsnaes, Thomas Risse and Beth A. Simmons (eds.) Handbook of International Relations. London: SAGE Publications, pp. 392-408.

Gow, James (1997). Triumph of the Lack of Will: International Diplomacy and the Yugoslav War. London: Hurst \& Company.

Green, David Michael, Chad Kahl and Paul F. Diehl (1998). "Predicting the size of UN peacekeeping operations," Armed Forces E Society, 24(4): 485-500.

Guisinger, Alexandra and Alastair Smith (2002). "Honest threat: the interaction of reputation and political institutions in international crises," Journal of Conflict Resolution, 46(2): 175-200.

Hartzell, Caroline, Matthew Hoddie and Donald Rothchild (2001). "Stabilizing the peace after civil war: an investigation of some key variables," International Organization, 55(1): 183-208.

Heldt, Birger (2004). "UN-led or non-UN-led peacekeeping operations?" IRI Review, 9(2): 113-138.

Heldt, Birger and Peter Wallensteen (2004). Peacekeeping Operations: Global Patterns of Intervention and Success, 1948-2000. Sandöverken: Folke Bernadotte Academy Publications.

Högbladh, Stina (2006). "Patterns of peace agreements: presenting new data on peace processes and peace agreements," paper delivered at the Annual Convention of the International Studies Association, San Diego, March 22-25. 
Jentleson, Bruce W. (1998). "Preventive diplomacy and ethnic conflict: possible, difficult, necessary," in David A. Lake and Donald Rothchild (eds.) The International Spread of Ethnic Conflict: Fear, Diffusion, and Escalation. Princeton: Princeton University Press, pp. 293-316.

Jervis, Robert (1970). The Logic of Images in International Relations. Princeton: Princeton University Press.

King, Gary, Michael Tomz and Jason Wittenberg (2000). "Making the most of statistical analyses: improving interpretation and presentation," American Journal of Political Science, 44(2): 347-361.

Kydd, Andrew (2004). "The honest broker: mediation and mistrust," paper prepared for the 2004 Annual Meeting of the American Political Science Association, Chicago, IL.

Melvern, Linda (2000). A People Betrayed: The Role of the West in Rwanda's Genocide. London: Zed Books.

Mercer, Jonathan (1996). Reputation and International Politics. Ithaca: Cornell University Press.

Oudraat, Chantal de Jonge (1996). "The United Nations and internal conflict," in Michael E. Brown (ed.) The International Dimensions of Internal Conflict. Cambridge, MA: MIT Press, pp. 489-535.

Richmond, Oliver (1998). "Devious objectives and the disputants' view of international mediation: a theoretical framework," Journal of Peace Research, 35(6): 707-722.

Saideman, Stephan M. (2002). "Overlooking the obvious: bringing international politics back into ethnic conflict management," International Studies Review, 4(3): 63-86.

Sambanis, Nicholas and Jonah Schulhofer-Wohl (2007). "Evaluating multilateral interventions in civil wars: a comparison of UN and non-UN peace operations," in Dimitris Bourantonis, Kostas Ifantis and Panayotis Tsakonas (eds.) Multilaterism and Security Institutions in an Era of Globalization. London and New York: Routledge.

Sartori, Anne E. (2002). "The might of the pen: a reputational theory of communication in international disputes," International Organization, 56(1): 121-149.

Schmidt, Holger (2005). "When (and why) do brokers have to be honest? impartiality and the effectiveness of third-party support for negotiated civil war settlements, 1945-1999," paper prepared for the 63rd Annual National Conference of the Midwest Political Science Association, Chicago, IL, April 7-10.

Schneidman, Witney W. (1993). "Conflict Resolution in Mozambique," in David R. Smock (ed.) Making War and Waging Peace: Foreign Intervention in Africa. Washington, DC: United States Institute of Peace Press.

Synge, Richard (1997). Mozambique: UN Peacekeeping in Action, 1992-1994. Washington, DC: United States Institute of Peace Press.

Toft, Monica Duffy (2004). The Geography of Ethnic Violence: Identity, Interests, and the Indivisibility of Territory. Princeton and Oxford: Princeton University Press.

Touval, Saadia (1994). "Why the U.N. fails," Foreign Affairs, September/ October: 44-57.

Uppsala Conflict Data Program (UCDP) (2005). Uppsala University. Online, available at: www.pcr.uu.se/gpdatabase/search.php.

Walter, Barbara F. (1997). "The critical barrier to civil war settlement," International Organization, 51 (3): 335-364. 


\section{I. Svensson}

Walter, Barbara F. (2002). Committing to Peace: The Successful Settlement of Civil Wars. Princeton and Oxford: Princeton University Press.

Walter, Barbara F. (2003). "Explaining the intractability of territorial conflict," International Studies Review, 5(4): 137-153.

Walter, Barbara F. (2006). "Information, uncertainty, and the decision to secede," International Organization, 60: 105-135. 


\section{References}

Andersson, Andreas (2000). "Democracies and UN peacekeeping operations, 1990-1996," International Peacekeeping, 7: 1-22.

Beardsley, Kyle and Holger Schmidt (2006). "(Almost) all a matter of supply: examining the determinants of UN involvement and effectiveness in International crises, 1945-2002," paper presented at the annual meeting of the American Political Science Association, Marriott, Loews Philadelphia, and the Pennsylvania Convention Center, Philadelphia, PA.

Bennett, D. Scott and Allan Stam (2000). "EUGene: a conceptual manual," International Interactions, 26: 179-204. Online, available at: http://eugenesoftware.org.

Benson, Michelle (2004). "Dyadic hostility and the ties that bind: state-to-state versus state-to-system security and economic relationships," Journal of Peace Research, 41: 659-676.

Bercovitch, Jacob (1999). "Mediation project data," Department of Political Science, University of Cantebury. Online, available at: www.posc.canterbury.ac.nz/ jbercovitch/mediation.html.

Bercovitch, Jacob and Allison Houston (1996). "The study of international mediation: theoretical issues and empirical evidence." in Jacob Bercovitch (ed.) Resolving International Conflicts: The Theory and Practice of Mediation. Boulder, CO: Lynne Rienner, pp. 11-35. 
Bercovitch, Jacob, Theodore Anagnoson and Donnette L. Wille (1991). "Some conceptual issues and empirical trends in the study of successful mediation in international relations," Journal of Peace Research, 28: 7-17.

Boehmer, Charles, Erik Gartzke and Timothy Nordstrom (2004). "Do intergovernmental organizations promote peace?” World Politics, 57: 1-38.

Butterworth, Robert Lyle (1978). "Do conflict managers matter? an empirical assessment of interstate security disputes and resolution efforts, 1945-1974," International Studies Quarterly, 22: 195-214.

Diehl, Paul F., Jennifer Reifschneider and Paul R. Hensel (1996). "United Nations intervention and recurring conflict," International Organization, 50: 683-700.

Dixon, William J. (1994). "Democracy and the peaceful settlement of international conflict," American Political Science Review, 88: 14-32.

Gartzke, Eric, Quan Li and Charles Boehmer (2001). "Investing in the peace: economic interdependence and international conflict," International Organization, 55: 391-438.

Gilligan, Michael and Stephen Stedman (2003). "Where do the peacekeepers go?" International Studies Review, 5: 37-54.

Greig, J. Michael (2001). "Moments of opportunity: recognizing conditions of ripeness for international mediation between enduring rivals," Journal of Conflict Resolution, 45: 691-718.

Haas, Ernst B. (1983). "Regime decay, conflict management and international organizations, 1945-1981," International Organization, 30: 189-256.

Jakobsen, Peter Viggo (1996). "National interest, humanitarianism or cnn: what triggers UN peace enforcement after the Cold War?" Journal of Peace Research, 33: 205-215.

Joffe, Josef (2002). "Mediation in the Middle East," The Washington Quarterly, 25: $171-175$

Journo, E. (2005). "The UN's 'virtue' is its vice: how the United Nation's neutrality props up evil regimes," Capital Magazine. Online., available at: www.capmag.com/ article.asp? ID=4416.

Kydd, Andrew (2003). "Which side are you on? Bias, credibility, and mediation," American Journal of Political Science, 47: 597-611.

Leeds, Brett Ashley (1999). "Domestic political institutions, credible commitments, and international cooperation," American Journal of Political Science, 43: 979-1002.

Lemke, Douglas and Suzanne Werner (1996). "Power parity, commitment to change, and war," International Studies Quarterly, 40: 235-260.

Maoz, Zeev and Nasrin Abdolali (1989). "Regime types and international conflict, 1817-1976," Journal of Conflict Resolution, 33: 3-35.

Maoz, Zeev and Bruce Russett (1993). "Normative and structural causes of democratic peace, 1946-1986," American Political Science Review, 87: 624-638.

Miller, Lynn H. (2001). "The idea and the reality of collective security," in Paul F. Diehl (ed.) The Politics of Global Governance. Boulder, CO: Lynn Reinner, pp. 171-201.

Neack, Laura (1995). "UN peace-keeping: in the interest of community or self?" Journal of Peace Research, 32: 181-196.

Oneal, John R. and Bruce Russett (1999). "The Kantian peace: the pacific benefits of democracy, independence, and international organizations, 1885-1992," World Politics, 52: 1-37.

Ouellet, Julian (2003). Peacemaking. Online, available at: www.beyondintractability. org/essay/peacemaking. 


\section{M. Benson and N.S. Satana}

Ratner, Steven R. (1995). "Image and reality in the UN's peaceful settlement of disputes," European Journal of International Law, 6: 426-444.

Russett, Bruce and John Oneal (2001). Triangulating Peace. New York: W.W. Norton \& Co.

Russett, Bruce, John R. Oneal and David R. Davis (1998). "The third leg of the Kantian tripod for peace: international organizations and militarized disputes, 1950-85," International Organization, 52: 441-467.

Smith, James D.D. (1994). "Mediator impartiality: banishing the chimera," Journal of Peace Research, 31: 445-450.

Tammen, Ronald L., Jacek Kugler, Douglas Lemke, Allan C. Stam III, Mark Abdollahian, Carole Alsharabati, Brian Efird and A.F.K. Organski (2000). Power Transitions: Strategic Policies for the 21st Century. New York: Chatham House.

Touval, Saadia and I. William Zartman (eds.) (1985). International Mediation in Theory and Practice. Boulder, CO: Westview Press.

Zartman, I. William and Saadia Touval (1996). "International mediation in the post-Cold War era," in Chester A. Crocker, Fen O. Hampson and Pamela R. Aall (eds.) Managing Global Chaos: Sources of and Responses to International Conflict. Washington, DC: United States Institute of Peace Press, pp. 445-461.

Ziring, Lawrence, Robert Riggs and Jack Plano (2005). The United Nations: International Organization and World Politics. Belmont, CA: Thomson Wadsworth. 


\section{References}

Allport, Gordon (1954). The Nature of Prejudice. Reading, MA: Addison-Wesley Publishing.

Amir, Yehuda (1998). "Contact hypothesis in ethnic relations," in Eugene Weiner (ed.) The Handbook of Interethnic Coexistence. New York: Continuum.

Beck, Nathaniel, Johnathan Katz and Richard Tucker (1998). "Taking time seriously: time-series-cross section analysis with a binary dependent variable," American Journal of Political Science, 42: 1260-1288.

Bercovitch, Jacob (1999). International Conflict Management database. Data and coding manual. Christchurch, New Zealand. Online, available at: www.pols. canterbury.ac.nz/jbercovitch/mediation.html, accessed August 9, 2005.

Bercovitch, Jacob and Paul Diehl (1997). "Conflict management of enduring rivalries: the frequency, timing, and short-term impact of mediation," International Interactions, 22: 299-320.

Blum, Douglas (1993). "The Soviet foreign policy belief system: beliefs, politics, and foreign policy outcomes," International Studies Quarterly, 37: 373-394.

Bonham, G. Matthew, Michael Shapiro, Thomas Trumble (1979). "The October War: changes in cognitive orientation toward the Middle East conflict," International Studies Quarterly, 23: 3-44.

Braumoeller, Bear (2004). "Hypothesis testing and multiplicative interaction terms," International Organization, 58: 807-820.

Cook, S.W. (1971). The Effect of Unintended Interracial Contact Upon Racial Interaction and Attitude Change. Washington, DC: Department of Health, Education, and Welfare.

Cook, S.W. (1984). “Cooperative interaction in multiethnic contexts," In N. Miller and M.B. Brewer (eds.) Groups in Contact: The Psychology of Desegregation. Orlando: Academic.

Crescenzi, Mark and Andrew J. Enterline (2001). "Time remembered: a dynamic model of interstate interaction," International Studies Quarterly, 45: 409-431.

Dixon, William (1994). "Democracy and the peaceful settlement of international conflict," American Political Science Review, 88: 14-32.

Fearon, James (1995). "Rationalist explanations for war," International Organization, 49: 379-414.

Fearon, James and David Laitin (1996). "Explaining interethnic cooperation," American Political Science Review, 90: 715-735. 
Filson, Darren and Suzanne Werner (2002). "A bargaining model of war and peace," American Journal of Political Science, 46: 819-838.

Fortna, Virginia P. (2004). "Where have all the victories gone? War outcomes in historical perspective," paper presented at the annual meeting of Peace Science Society (International), Houston.

Frazier, Derrick (2005). "Third party characteristics, territory and the mediation of militarized interstate disputes," draft manuscript.

Gaertner, Samuel, John Dovidio and Betty Bachman (1996). "Revisiting the contact hypothesis: the induction of a common ingroup identity," International Journal of Intercultural Relations, 20: 271-290.

Ghosn, Faten, Glenn Palmer and Stuart Bremer (2004). "The MID3 data set, 1993-2001: procedures, coding rules, and description," Conflict Management and Peace Science, 21: 133-154.

Goemans, Hein (2003). War and Punishment: The Causes of War Termination and the First World War. Princeton: Princeton University Press

Goertz, Gary and Paul F. Diehl (2002). "Treaties and conflict management in enduring rivalries," International Negotiation, 7: 379-398.

Goertz, Gary, Bradford Jones and Paul F. Diehl (2005). "Maintenance processes in international rivalries," Journal of Conflict Resolution, 49(5): 742-769.

Goldstein, Joshua (1992). "A conflict-cooperation scale for weis international events data," Journal of Conflict Resolution, 36: 369-385.

Greig, J. Michael (2001). "Moments of opportunity: recognizing conditions of ripeness for international mediation between enduring rivals," Journal of Conflict Resolution, 45: 691-718.

Greig, J. Michael (2005). "Stepping into the fray: when do mediators mediate?" American Journal of Political Science, 49: 249-266.

Grieco, Joseph (2001). "Repetitive military challenges and recurrent international conflicts, 1918-1994," International Studies Quarterly, 45: 295-316.

Griffiths, Franklyn (1989). "The Soviet experience of arms control," in Janice Gross Stein (ed.) Getting to the Table. Baltimore: Johns Hopkins University Press.

Hensel, Paul R. (1994). "One Thing leads to another: recurrent militarized disputes in Latin America, 1816-1986,” Journal of Peace Research, 31: 281-298.

Hensel, Paul, Gary Goertz and Paul F. Diehl (2000). "The Democratic peace and rivalries," Journal of Politics, 62: 1173-1188.

Holbrooke, Richard (1998). To End a War. New York: Random House.

Holsti, Ole (1967). "Cognitive dynamics and images of the enemy," Journal of International Affairs, 21: 16-39.

Kelman, Herbert (1996). "The interactive problem-solving approach," In C.A. Crocker, F.O. Hampson and Pamela R. Aall (eds.) Managing Global Chaos: Sources of and Responses to International Conflict. Washington, DC: United States Institute of Peace Press.

Kleiboer, Marieke (1994). "Ripeness of conflict: a fruitful notion?" Journal of Peace Research, 31: 109-116.

Klein, James, Gary Goertz and Paul F. Diehl (2004). The new rivalry dataset: procedures and patterns. Online, available at: ftp://128.196.23.212/rivalry/ riv500web.zip.

Lebow, Richard Ned (1981). Between Peace and War. Baltimore: Johns Hopkins University Press. 
Lederach, John Paul (1997). Building Peace: Sustainable Reconciliation in Divided Societies. Washington, DC: United States Institute of Peace Press.

Long, J. Scott and Jeremy Freese (2001). Regression Models for Categorical Dependent Variables Using Stata. College Station, TX: Stata Press.

McEwen, C.A. and T.W. Milburn (1993). "Explaining the paradox of mediation," Negotiation Journal, 9: 23-36.

McGinnis, Michael and John Williams (2000). Compound Dilemmas. Ann Arbor: University of Michigan Press.

Maoz, Ifat (2005). "Evaluating the communication between groups in dispute: equality in contact interventions between Jews and Arabs in Israel," Negotiation Journal, 21: 131-146.

Maoz, Zeev (1990). Paradoxes of War. Boston: Unwin Hyman.

Marshall, Monty G. and Keith Jaggers (2002). Polity IV Project: Political Regime Characteristics and Transitions, 1800-2002. Online, available at: www.cidcm. umd.edu/inscr/polity/index.htm, accessed August 9, 2005.

Most, Benjamin and Harvey Starr (1989). Inquiry, Logic, and International Politics. Columbia: University of South Carolina Press.

Oneal, John R. and Bruce Russett (1999). "Assessing the liberal peace with alternative specifications: trade still reduces conflict," Journal of Peace Research, 36: 423-432.

Pettigrew, Thomas (1998). "Intergroup contact theory," Annual Review of Psychology, 49: 65-85.

Pevehouse, Jon, Timothy Nordstrom and Kevin Warnke (2004). "The Correlates of War 2 international governmental organizations data version 2.0," Conflict Management and Peace Science, 21: 101-119.

Powell, Robert (1990). Nuclear Deterrence Theory: The Search for Credibility. New York: Cambridge University Press.

Powell, Robert (2004). "Bargaining and learning while fighting over the distribution of power," American Journal of Political Science, 48: 344-361.

Princen, Thomas (1992). Intermediaries in International Conflict. Princeton: Princeton University Press.

Pruitt, Dean and Paul Olczak (1995). "Beyond hope: approaches to resolving seemingly intractable conflict," in Barbara Bunker and Jeffrey Rubin (eds.) Conflict, Cooperation, and Justice. San Francisco: Jossey-Bass.

Pruitt, Dean and Jeffrey Rubin (1986). Social Conflict: Escalation, Stalemate, and Settlement. New York: Random House.

Regan, Patrick and Allan Stam (2000). "In the nick of time," International Studies Quarterly, 44: 239-260.

Reiter, Dan (2003). "Exploring the bargaining model of war," Perspectives on Politics, 1: 27-43.

Richmond, Oliver (1998). "Devious objectives and the disputants' view of international mediation: a theoretical framework," Journal of Peace Research, 35: 707-722.

Rosen, Stephen (2005). War and Human Nature. Princeton: Princeton University Press.

Ross, L. and A. Ward (1995). "Psychological barriers to dispute resolution," Advances in Experimental Social Psychology, 27: 255-304.

Rubin, Jeffrey (1991). "The timing of ripeness and the ripeness of timing," in Louis Kriesberg and Stuart J. Thorson (eds.) Timing the De-Escalation of International Conflicts. Syracuse, NY: Syracuse University Press.

Rubin, Jeffrey (1992). "Conclusion: international mediation in context," in Jacob 
Bercovitch and Jeffrey Rubin (eds.) Mediation in International Relations: Multiple Approaches to Conflict Management. New York: St. Martin's Press.

Rubin, Jeffrey, Dean Pruitt and S. Kim (1994). Social Conflict: Escalation, Stalemate, and Settlement. New York: McGraw-Hill.

Russett, Bruce (1993). Grasping the Democratic Peace. Princeton: Princeton University Press.

Sarkees, Meredith Reid (2000). "The Correlates of War data on war: an update to 1997," Conflict Management and Peace Science, 18: 123-144.

Sherif, M. and C.W. Sherif (1953). Groups in Harmony and Tension: An Integration of Studies in Intergroup Relations. New York: Harper.

Slantchev, Branislav (2002). "The power to hurt: costly conflict with completely informed states," American Political Science Review, 47: 1-11.

Smith, Alastair and Allan Stam (2003). "Mediation and peacekeeping in a random walk model of civil and interstate war," International Studies Review, 5: 115-135.

Smith, Alastair and Allan Stam (2004). "Bargaining and the nature of war," Journal of Conflict Resolution, 48: 783-813.

Spector, Bertram (1998). "Deciding to negotiate with villains," Negotiation Journal, 14: 43-60.

Stein, Janice Gross (1989). "Getting to the table: the triggers, stages, functions, and consequences of prenegotiation," in Janice Gross Stein (ed.) Getting to the Table. Baltimore: Johns Hopkins University Press.

Stein, Janice Gross (1996) "Image identity and conflict resolution," in C.A. Crocker, F.O. Hampson, Pamela R. Aall (eds.) Managing Global Chaos: Sources of and Responses to International Conflict. Washington, DC: United States Institute of Peace Press.

Stinnett, Douglas and Paul F. Diehl (2001). "The path(s) to rivalry: behavioral and structural explanations of rivalry development," Journal of Politics, 63: 717-740.

Tetlock, Philip (1994). "Social psychology and world politics," in D. Gilbert, S. Fiske and G. Lindsay (eds.) Handbook of Social Psychology, 4th edn. Boston: McGraw-Hill.

Wagner, R. Harrison (2000). "Bargaining and war," American Journal of Political Science, 44: 469-484.

Walter, Barbara (2002). Committing to Peace: The Successful Settlement of Civil Wars. Princeton: Princeton University Press.

Watkins, Michael and Kirsten Lundberg (1998). "Getting to the table in Oslo: driving forces and channel factors," Negotiation Journal, 14: 115-134.

Young, Oran (1967). The Intermediaries: Third Parties in International Crises. Princeton: Princeton University Press.

Zartman, I. William (1985). Ripe for Resolution: Conflict and Intervention in Africa. New York: Oxford University Press.

Zartman, I. William (2000). "Ripeness: the hurting stalemate and beyond," in Paul Stern and Daniel Druckman (eds.) International Conflict Resolution After the Cold War. Washington, DC: National Academy Press.

Zartman, I. William and Saadia Touval (1996). "International Mediation in the post-Cold War era," in C.A. Crocker, F.O. Hampson and Pamela R. Aall (eds.) Managing Global Chaos: Sources of and Responses to International Conflict. Washington, DC: United States Institute of Peace Press. 


\section{References}

Achen, Christopher (1986). The Statistical Analysis of Quasi-experiments. Berkeley, CA: University of California Press.

Aggestam, Karin (2002). "Mediating asymmetrical conflict," Mediterranean Politics, 7(1): 69-91.

Agusti-Panareda, Jordi (2004). "Power imbalances in mediation: questioning some common assumptions," Dispute Resolution Journal, 59 (2): 24-31.

Beardsley, Kyle (2004). "Seeking counseling: the strategic selection of mediation in international crises," paper presented at the Annual Meeting of the Peace Science Society, Houston.

Beardsley, Kyle, David Quinn, Bidisha Biswas and Jonathan Wilkenfeld (2006). "Mediation style and crisis outcomes," Journal of Conflict Resolution, 50(1): 58-86.

Bercovitch, Jacob (1986). "International mediation: a study of the incidence, strategies and conditions of successful outcomes," Cooperation and Conflict, 21(3): $155-168$.

Bercovitch, Jacob (1992). "The structure and diversity of mediation in international relations," in Jacob Bercovitch and Jeffrey Z. Rubin (eds.) Mediation in International Relations. New York: St. Martin's Press, pp. 1-29.

Bercovitch, Jacob (1996). "Understanding mediation's role in preventive diplomacy," Negotiation Journal, 12(4): 241-258.

Bercovitch, Jacob (1997). "Mediation in international conflict: an overview of theory, a review of practice," in I. William Zartman and J. Lewis Rasmussen (eds.) Peacemaking in International Conflict: Methods and Techniques. Washington, DC: United States Institute of Peace Press, pp. 125-153.

Bercovitch, Jacob and Allison Houston (1996). "The study of international mediation: theoretical issues and empirical evidence," in Jacob Bercovitch (ed.) Resolving International Conflicts: The Theory and Practice of Mediation. Boulder, CO: Lynne Rienner, pp. 11-35.

Bercovitch, Jacob and Richard Jackson (2001). "Negotiation or mediation? An exploration of factors affecting the choice of conflict management in international conflict," Negotiation Journal, 17(1): 59-77.

Bercovitch, Jacob, and Jeffrey Langley (1993). "The nature of the dispute and the effectiveness of international mediation," Journal of Conflict Resolution, 37(4): 670-699.

Bercovitch, Jacob, J. Theodore Anagnoson and Donnette L. Wille (1991). "Some conceptual issues and empirical trends in the study of successful mediation in international relations," Journal of Peace Research, 28(1): 7-17.

Brecher, Michael and Jonathan Wilkenfeld (2000). A Study of Crisis, 2nd edn. Ann Arbor: University of Michigan Press.

Burton, John W. (1984). Global Conflict: The Domestic Sources of International Crisis. Brighton, UK: Wheatsheaf Books. 
Carnevale, Peter (1986). "Strategic choice in mediation," Negotiation Journal, 2(1): 41-56.

Claude, Inis (1962). Power and International Relations. New York: Random House.

Deutsch, Morton (1973). The Resolution of Conflict: Constructive and Destructive Processes. New Haven, CT: Yale University Press.

Dixon, William J. (1996). "Third-party techniques for preventing conflict escalation and promoting peaceful settlement," International Organization, 50(4): 653-681.

Fearon, James (1995). "Rationalist explanations for war," International Organization, 49(3): 379-414.

Fisher, Ronald J. (1972). "Third party consultation: a method for the study and resolution of conflict," Journal of Conflict Resolution, 16(1): 67-94.

Greig, J. Michael (2001). "Moments of opportunity: recognizing conditions of ripeness for international mediation," Journal of Conflict Resolution, 45(6): 691-718.

Greig, J. Michael (2005). "Stepping into the fray: when do mediators mediate?" American Journal of Political Science, 49(2):249-266.

Hopmann, P. Terrence (1996). The Negotiation Process and the Resolution of International Conflicts. Columbia: University of South Carolina Press.

Keashly, Loraleigh and Ronald J. Fisher (1996). "A contingency perspective on conflict interventions: theoretical and practical considerations," in Jacob Bercovitch (ed.) Resolving International Conflicts: The Theory and Practice of Mediation. Boulder, CO: Lynne Rienner, pp. 235-261.

Kelman, Herbert C. (1992). "Informal mediation by the scholar/practitioner," in Jacob Bercovitch and Jeffrey Z. Rubin (eds.) Mediation in International Relations. New York: St. Martin's Press, pp. 64-96.

King, Gary, Michael Tomz and Jason Wittenberg (2000). "Making the most of statistical analyses: improving interpretation and presentation," American Journal of Political Science, 44(2): 341-355.

Kleiboer, Marieke (1996). "Understanding success and failure of international mediation," Journal of Conflict Resolution, 40(2): 360-390.

Kriesbeg, Louis (1982). Social conflicts, 2nd edn. Englewood Cliffs, NJ: Prentice-Hall. Kugler, Jacek and Douglas Lemke (eds.) (1996). Parity and War: Evaluations and Extensions of the War Ledger. Ann Arbor: University of Michigan Press.

Lemke, Douglas and William Reed (2001). "War and rivalry among great powers," American Journal of Political Science, 45(2): 457-469.

Mitchell, Christopher (1993). "The process and stages of mediation: two Sudanese cases," in David R. Smock (ed.) Making War and Waging Peace: Foreign Intervention in Africa. Washington, DC: United States Institute of Peace Press, pp. 139-159.

Nickles, Ralph Warner and Joanne Hedgespeth (1991). "A generic model for divorce mediation," Journal of Divorce and Remarriage, 17(1/2): 157-169.

Organski, A.F.K. (1968). World Politics. New York: Knopf.

Organski, A.F.K. and Jacek Kugler (1980). The War Ledger. Chicago, IL: University of Chicago Press.

Ott, Marvin C. (1972). "Mediation as a method of conflict resolution: two cases," International Organization, 26(4): 595-618.

Pfetsch, Frank R. and Alice Landau (2000). "Symmetry and asymmetry in international negotiations," International Negotiation, 5(1): 21-42. 
Powell, Robert (1999). In the Shadow of Power: States and Strategies in International Politics. Princeton: Princeton University Press.

Princen, Thomas (1992). Intermediaries in International Conflict. Princeton: Princeton University Press.

Pruitt, Dean G. and Peter J. Carnevale (1993). Negotiation in Social Conflict. Pacific Grove, CA: Brooks/Cole Publishing Co.

Raymond, Gregory A. and Charles W. Kegley, Jr. (1985). "Third party mediation and international norms: a test of two models," Conflict Management and Peace Science, 9(1): 33-51.

Richmond, Oliver (1998). "Devious objectives and the disputants' view of international mediation: a theoretical framework," Journal of Peace Research, 35(6): $707-722$.

Rouhana, Nadim M. and Susan H. Korper (1997). "Power asymmetry and goals of unofficial third party intervention in protracted intergroup conflict," Peace and Conflict: Journal of Peace Psychology, 3 (1): 1-17.

Rubin, Jeffrey Z. and Bert R. Brown (1975). The Social Psychology of Bargaining and Negotiation. New York: Academic Press.

Rubin, Jeffrey Z. and I. William Zartman (1995). "Asymmetrical negotiations: some survey results that may surprise," Negotiation Journal, 11 (4): 349-364.

Singer, J. David (1963). “Inter-nation influence: a formal model,” American Political Science Review, 57(2): 420-430.

Touval, Saadia (1982). The Peace Brokers: Mediators in the Arab-Israeli Conflict, 1948-1979. Princeton: Princeton University Press.

Touval, Saadia and I. William Zartman (1985). "Introduction: mediation in theory," in Saadia Touval and I. William Zartman (eds.) International Mediation in Theory and Practice. Boulder, CO: Westview Press, pp. 7-17.

Wall, James A. and Ann Lynn (1993). "Mediation: a current review," Journal of Conflict Resolution, 37(1): 160-194.

Wall, James A., John B. Stark and Rhetta L. Standifer (2001). "Mediation: a current review and theory development," Journal of Conflict Resolution, 45(3): 370-391.

Wilkenfeld, Jonathan, Kathleen Young, Victor Asal and David Quinn (2003). "Mediating international crises: cross-national and experimental perspectives," Journal of Conflict Resolution, 47: 279-301.

Wilkenfeld, Jonathan, Kathleen Young, David Quinn and Victor Asal (2005). Mediating International Crises. London: Routledge.

Wright, Quincy (1965). A Study of War, 2nd edn. Chicago, IL: University of Chicago Press.

Young, Oran R. (1967). The Intermediaries: Third Parties in International Crises. Princeton: Princeton University Press.

Zartman, I. William (1981). "Explaining disengagement," in Jeffrey Z. Rubin (ed.) Dynamics of Third Party Intervention: Kissinger in the Middle East. New York: Praeger, pp. 148-170.

Zartman, I. William (1995a). "Dynamics and constraints in negotiations in internal conflicts," in I. William Zartman (ed.) Elusive Peace: Negotiating an End to Civil Wars. Washington, DC: Brookings Institution, pp. 3-29.

Zartman, I. William (1995b). "Conclusions: the last mile," in I. William Zartman (ed.) Elusive Peace: Negotiating an End to Civil Wars. Washington, DC: Brookings Institution, pp. 332-346. 
Zartman, I. William (2000). "Ripeness: the hurting stalemate and beyond," in Paul C. Stern and Daniel Druckman (eds.) International Conflict Resolution after the Cold War. Washington, DC: National Academy Press, pp. 225-250.

Zartman, I. William and Jeffrey Z. Rubin (2000). "The study of power and the practice of negotiation," in I. William Zartman and Jeffrey Z. Rubin (eds.) Power and Negotiation. Ann Arbor: University of Michigan Press, pp. 3-28.

Zartman, I. William and Saadia Touval (1996). "International mediation in the post-Cold War era," in C.A. Crocker, F.O. Hampson and Pamela R. Aall (eds.) Managing Global Chaos: Sources of and Responses to International Conflict. Washington, DC: United States Institute of Peace Press, pp. 445-461. 


\section{References}

Azar, Edward E. (1990). The Management of Protracted Social Conflict, Theory and Cases. Hampshire, UK: Dartmouth.

Azar, Edward E., Paul Jouredeini and Ronald McLaurin (1978). "Protracted social conflict: theory and practice in the Middle East," Journal of Palestine Studies, 1: 41-60.

Beardsley, Kyle Clark, David Quinn, Bidisha Biswas and Jonathan Wilkenfeld (2006). "Mediation style and crisis outcomes," Journal of Conflict Resolution, 50(1): 58-86.

Bercovitch, Jacob (1991). "International mediation," Journal of Peace Research: Special Issue on International Mediation, 28(1): 3-6.

Bercovitch, Jacob (1996a). Resolving International Conflicts: The Theory and Practice of Mediation. Boulder, CO: Lynne Rienner Publishers.

Bercovitch, Jacob (1996b). "Understanding mediation's role in preventive diplomacy," Negotiation Journal, 12(3): 241-258.

Bercovitch, Jacob, and Allison Houston (1996). "The study of international mediation: theoretical issues and empirical evidence," in Jacob Bercovitch (ed.) Resolving International Conflicts. Boulder, CO: Lynne Rienner Publishers, pp. 11-35.

Bercovitch, Jacob and Patrick M. Regan (1997). "Managing risks in international relations: the mediation of enduring rivalries," Gerald Schneider and Patricia A. Weitsman (eds.) Enforcing Cooperation. New York: St. Martin's Press, pp. 185-201.

Bercovitch, Jacob, Theodore Anagnoson and Donette Wille (1991) "Some conceptual issues and empirical trends in the study of successful mediation in international relations," Journal of Peace Research: Special Issue on International Mediation, 28(1), 7-17.

Bouffard, S. and D. Carment (2006). "The Sri Lanka peace process: a critical review," Journal of South Asian Development, 1(2): 151-177.

Brecher, Michael (1993). Crises in World Politics. London: Pergamon Press. 
Brecher, Michael and Patrick James (1988). "Patterns of crisis management," Journal of Conflict Resolution, 32(3): 426-456.

Brecher, Michael and Jonathan Wilkenfeld (with Patrick James) (1989b). Crisis, Conflict and Instability. Oxford: Pergamon Press.

Brecher, Michael and Jonathan Wilkenfeld (1997). "The ethnic dimension of international crises," in David Carment and Patrick James (eds.) Wars in the Midst of Peace: The International Politics of Ethnic Conflict. Pittsburgh: University of Pittsburgh Press.

Dixon, William J. (1996). "Third party techniques for preventing conflict escalation and promoting peaceful settlement," International Organization, 50(4): 653-681.

Haas, Ernst (1993). "Collective conflict management: evidence for a new world order?” in Thomas G. Weiss (ed.) Collective Security in a Changing World. Boulder, CO and London: Lynne Rienner Publishers, pp. 61-117.

Kleiboer, Marieke (1996). "Understanding success and failure of international mediation," Journal of Conflict Resolution, 40(2): 360-389.

Lake, David A. and Donald Rothchild (1996). "Containing fear: the origins and management of ethnic conflict," International Security, 21 (2): 41-75.

Lund, Michael S. (1996). Preventing Violent Conflict: A Strategy for Preventive Diplomacy, Washington, DC: United States Institute of Peace Press.

Regan, Patrick (1996a) "Conditions of successful third-party intervention in intrastate conflicts,” Journal of Conflict Resolution, 40(2): 336-359.

Regan, Patrick (1996b). "Interventions into intense intrastate conflicts: minimizing the uncertainty in the decision process," ISA paper, San Diego.

Vayrynen, Raimo (1996). "Strategies for conflict resolution in the 21st century," CASID Distinguished Speaker Series no. 15. Michigan State University, Center for Advanced Study of International Development.

Wall, James A. and Daniel Druckman (2003). "Mediation in peacekeeping missions" Journal of Conflict Resolution, 47(5): 693-705.

Zartman, William I. (1992). "Internationalization of communal strife: temptations and opportunities of triangulation," in Manus, I. Midlarsky (ed.) The Internationalization of Communal Strife. London: Routledge, pp. 4-24. 


\section{References}

Axelrod, Robert (1984). The Evolution of Cooperation. New York: Basic Books.

Berkovitch, Jacob and Gerald Schneider (2000). "Who Mediates? The Political economy of international crisis management," Journal of Peace Research, 37(2): 145-165.

Bull, Hedley (1977). The Anarchical Society: A Study of Order in World Politics. New York: Columbia University.

Bull, Hedley (1995). The Anarchical Society, 2nd edn. London: Macmillan.

Claude, Inis L. Jr. (1966). "Collective legitimization as a political function of the U.N.," International Organization, 20(3): 367-379.

Crescenzi, Mark J.C. and Andrew J. Enterline (1999). "Ripples from the waves? A Systemic, time-series analysis of democracy, democratization, and interstate war," Journal of Peace Research, 36(1): 75-94.

Crescenzi, Mark J.C. and Andrew J. Enterline (2001). "Time remembered: a dynamic model of interstate interaction," International Studies Quarterly, 45(3): 371-393.

Crescenzi, Mark J.C., Kelly M. Kadera, Sara McLaughlin Mitchell and Clayton L. Thyne (2007). "A supply side theory of mediation," working paper.

Dixon, William J. (1993). "Democracy and the management of international conflict," Journal of Conflict Resolution, 37(1): 42-68.

Dixon, William J. (1994). "Democracy and the peaceful settlement of international conflict,” American Political Science Review, 88(1): 14-32.

Dixon, William J. (1996). "Third-party techniques for preventing conflict escalation and promoting peaceful settlement," International Organization, 50(4): 653-681.

Fearon, James D. (1995). "Rationalist explanations for war," International Organization, 49(3): 379-414.

Finnemore, Martha and Kathryn Sikkink (1998). "International norm dynamics and political change," International Organization, 52(4): 887-917. 
Gaubatz, Kurt Taylor (1996). "Democratic states and commitment in international relations," International Organization, 50(1): 109-139.

Gleditsch, Nils Petter and Håvard Hegre (1997). "Peace and democracy: three levels of analysis," Journal of Conflict Resolution, 41 (2): 283-310.

Goertz, Gary and Patrick Regan (1997). "Conflict management in enduring rivalries," International Interactions, 22(4): 321-340.

Grigorescu, Alexandru (2003). "International organizations and government transparency: linking the international and domestic realms," International Studies Quarterly, 47(4): 643-667.

Harrison, Ewan (2002). "Waltz, Kant, and systemic approaches to international relations," Review of International Studies, 28(1): 143-162.

Hensel, Paul R. (2001). "Contentious issues and world politics: the management of territorial claims in the americas, 1816-1992," International Studies Quarterly, 45(1): 81-109.

Hensel, Paul R., Sara McLaughlin Mitchell, Thomas E. Sowers II and Clayton L. Thyne (2008). "Bones of contention: comparing territorial, maritime, and river issues," Journal of Conflict Resolution, 52(1): 117-143.

Holsti, Kalevi J. (1991). Peace and War: Armed Conflicts and International Order 1648-1989. Cambridge: Cambridge University Press.

Ikenberry, G. John and Charles Kupchan (1990). "Socialization and hegemonic power," International Organization, 44(3): 283-315.

Kadera, Kelly M. and Sara McLaughlin Mitchell (2005). "Heeding Ray's advice: an exegesis on control variables in systemic democratic peace research," Conflict Management and Peace Science, 22(4): 311-326.

Kadera, Kelly M., Mark J.C Crescenzi and Megan L. Shannon (2003). "Democratic survival, peace, and war in the international system," American Journal of Political Science, 47(2): 234-247.

Keohane, Robert O. (1984). After Hegemony: Cooperation and Discord in the World Political Economy. Princeton: Princeton University Press.

Leeds, Brett Ashley (1999). "Domestic political institutions, credible commitments, and international cooperation," American Journal of Political Science, 43(4): 979-1002.

Levi, Werner (1991). Contemporary International Law, 2nd edn. Boulder, CO: Westview Press.

Lipson, Charles (2003). Reliable Partners: How Democracies Have Made a Separate Peace. Princeton: Princeton University Press.

McGillivray, Fiona and Alastair Smith (2000). "Trust and cooperation through agent-specific punishments," International Organization, 54(4): 809-824.

Maoz, Zeev and Bruce Russett (1993). "Normative and structural causes of democratic peace, 1946-1986,” American Political Science Review, 87(3): 624-638.

Marshall, Monty G. and Keith Jaggers (2000). Polity IV dataset. Online, available at: www.bsos.umd.edu/cidcm/inscr.

Mitchell, Sara McLaughlin (2002). "A Kantian system? Democracy and third-party conflict resolution," American Journal of Political Science, 46(4): 749-759.

Mitchell, Sara McLaughlin and Paul R. Hensel (2007). "International institutions and compliance with agreements," American Journal of Political Science, 51 (4): 721-737.

Mitchell, Sara McLaughlin and Brandon C. Prins (1999). "Beyond territorial contiguity: issues at stake in democratic militarized interstate disputes," International Studies Quarterly, 43(1): 169-183. 
Mitchell, Sara McLaughlin, Scott Gates and Håvard Hegre (1999). "Evolution in democracy-war dynamics," Journal of Conflict Resolution, 43(6): 771-792.

Pevehouse, Jon and Bruce Russett (2006). "Democratic international governmental organizations promote peace," International Organization, 60(4): 969-1000.

Powell, Emilia Justyna and Sara McLaughlin Mitchell (2007). "The International Court of Justice and the world's three legal systems," Journal of Politics, 69(2): 397-415.

Putnam, Robert D. (1988). "Diplomacy and domestic politics: the logic of two-level games," International Organization, 42(3): 427-460.

Raymond, Gregory A. (1994). "Democracies, disputes, and third-party intermediaries," Journal of Conflict Resolution, 38(1): 24-42.

Risse-Kappen, Thomas (1995). Cooperation Among Democracies: The European Influence on U.S. Foreign Policy. Princeton: Princeton University Press.

Russett, Bruce and John M. Oneal (2001). Triangulating Peace: Democracy, Interdependence, and International Organizations. New York: Norton.

Simmons, Beth (1999). "See you in 'court'? The appeal to quasi-judicial legal processes in the settlement of territorial disputes," in Paul F. Diehl (ed.) A Road Map to War: Territorial Dimensions of International Conflict. Nashville: Vanderbilt University Press.

Singer, J. David, Stuart Bremer and J. Stuckey (1972). "Capability distribution, uncertainty, and major power war, 1820-1965," in Bruce Russett (ed.) Peace, War, and Numbers. Beverly Hills: Sage.

Starr, Harvey and Christina Lindborg (2003). "Democratic dominoes revisited: the hazards of governmental transitions, 1974-1996," Journal of Conflict Resolution, 47(4): 490-519.

Sullivan, Patricia L. and S. Scott Gartner (2006). "Disaggregating peace: domestic politics and dispute outcomes," International Interactions, 32(1): 1-26.

Toope, Stephen (1999). "Re reference by governor in council concerning certain questions relating to secession of Quebec from Canada. 161 D.L.R. (4th) 385," American Journal of International Law, 93(2): 519-525. 
J.A. Wall et al.

\section{References}

Bandura, A. (1977). Social Learning Theory. Upper Saddle river, NJ: Prentice-Hall. Bercovitch, J. (1996). "Understanding mediation's role in preventive diplomacy," Negotiation Journal, 12: 241-258.

Bercovitch, J. and A. Houston (1993). "Influence of mediator characteristics and behavior on the success of mediation in international relations," International Journal of Conflict Management, 4: 297-321. 
Beteille, A. (1965). Caste, Class and Power: Changing Patterns of Stratification in a Tanjore Village. Los Angeles: University of California Press.

Bond, R. and P. Smith (1996). "Culture and conformity: a meta-analysis of studies using Asch's (1952-1956) live judgment task," Psychological Bulletin, 119: 111-137.

Callister, R.R. and J. Wall (2001). "Conflict across organizational boundaries: managed care organizations versus health care providers," Journal of Applied Psychology, 86: 754-763.

Callister, R.R. and J. Wall (2004). "Thai and U.S. community mediation," Journal of Conflict Resolution, 48: 573-598.

Cialdini, R. (1988). Influence: Science and Practice. Glenview, IL: Scott Foresman and Company.

Cohen, J.A. (1966). "Chinese mediation on the eve of modernization," California Law Review, 54: 1201-1226.

Conlon, D.E., P.J. Carnevale and K. Murnighan (1994). "Intravention: third-party intervention with clout," Organizational Behavior and Human Decision Processes, 57: $387-410$.

Cortazzi, H. (1990). The Japanese Achievement. London: Sidgwick and Jackson.

Depner, C.E., K. Cannata and I. Ricci (1994). "Client evaluations of mediation services: the impact of case characteristics and mediation service models," Family and Conciliation Courts Review, 32: 306-325.

Druckman, D. and J. Green (1986). "Political stability in the Philippines: framework and analysis," in Denver Monograph Series in World Affairs No. 22, Book 3. Denver, CO: University of Denver.

Druckman, D., J.N. Druckman and T. Arai (2004). "e-Mediation: evaluating the impacts of an electronic mediator on negotiating behavior," Group Decision and Negotiation, 13: 481-511.

Grillo, T. (1991). "The mediation alternative: process dangers for women," The Yale Law Journal, 100: 1545-1610.

Haney, C., W.C. Banks and P.G. Zimbardo (1973). "Interpersonal dynamics in a simulated prison," International Journal of Criminology and Penology, 1: 69-97.

Herkovits, M. (1955). Cultural Anthropology. New York: Knopf.

Johnson, D.W., R.T. Johnson, B. Dudley, M. Ward and D. Magnnson (1995). "The impact of peer mediation training on the management of school and home conflicts," American Educational Research Journal, 32: 829-844.

Judicial Yuan (2006). Taiwan Code of Civil Procedure. Taipei: Judicial Yuan, Republic of China.

Kim, M. (1986). "The characteristics of village life and hyangyak in the middle of the Yi dynasty," Research in Korean History, 55: 11-46.

Kim, N., J.A. Wall, D.W. Sohn and J.S. Kim (1993). "Community and industrial mediation in South Korea,” Journal of Conflict Resolution, 37: 361-382.

Kipnis, D. (1976). The Powerholders. Chicago: University of Chicago Press.

Kraus, S.J. (1995). "Attitudes and the prediction of behavior: a meta-analysis of the empirical literature,” Personality and Social Psychology Bulletin, 21: 58-75.

Kressel, K. and D.G. Pruitt (1985). "Themes in the mediation of social conflict," Journal of Social Issues, 41: 179-198.

Kressel, K. and D.G. Pruitt (1989). Mediation Research. San Francisco: Jossey-Bass.

Levitt, M.A. (1997). "Kilometer 101: oasis or mirage? An analysis of third-party self-interest in international mediation," Mediation Quarterly, 15: 155-176. 
Locke, E.A. (1991). "The motivation sequence, the motivational hub, and the motivation core," Organizational Behavior and Human Decision Processes, 50: 288-299.

Lopez, J.V. (2004). The Law on Alternative Dispute Resolution. New York: Rex Book Store.

Luthans, F. and R. Keitner (1985). Organizational Behavior Modification and Beyond: An Operant and Social Learning Approach. Glenview, IL: Scott Foresman.

McClelland, D.C. (1961). "The two faces of power," Journal of International Affairs, 24: $141-154$.

Martinez-Pecino, R., L. Munduate and E. Martin (2006). "Labour conflict mediation in Andalusia," paper presented at IACM meeting, June 25-28, Montreal, Canada.

Meglino, B.M. and E.C. Ravlin (1989). "Individual values in organizations: concepts, controversies and research," Journal of Management, 24: 351-389.

Mumpower, J.L. and Rohrbaugh, J. (1996). "Negotiation and design: supporting resource allocation decisions through analytical mediation," Group Decision and Negotiation, 5: 385-409.

Pruitt, D.G., N.B. McGillicuddy, G.L. Welton and W.R. Fry (1989). "Process of mediation in dispute settlement centers," in K. Kressel and D.G. Pruitt (eds.) Mediation Research. San Francisco: Jossey-Bass, pp. 368-393.

Shemberg, A. (1997). "Mediation as an alternative method of dispute resolution for the individuals with disabilities education act: a just proposal?" Ohio State Journal on Dispute Resolution, 12: 739-757.

Siero, S., M. Boon, G. Kok and F. Siero (1989). "Modification of driving behavior in a large transport organization: a field experiment," Journal of Applied Psychology, 74: 417-423.

Triandis, H. (1994). Culture and Social Behavior. New York: McGraw-Hill.

Vanayan, M., N. White, P. Yuen and M. Teper (1997). "Would you like to be a peer mediator? Willingness to be a peer mediator among elementary students: effects of grade and gender," Alberta Journal of Educational Research, 43: 57-60.

Vroom, V.H. (1964). Work and Motivation. New York: John Wiley.

Wall, J.A. and M. Blum (1991). "Community mediation in the People's Republic of China," Journal of Conflict Resolution, 35: 3-20.

Wall, J.A. and R.R. Callister (1999). "Malaysian community mediation," Journal of Conflict Resolution, 43: 343-365.

Wall, J.A., V. Arunachalam and R.R. Callister (in press). "Indian and U.S. community mediation," Journal of Applied Social Psychology.

Wall, J.A., J.B. Stark and R.L. Standifer (2001). "Mediation: a current review and theory development," Journal of Conflict Resolution, 45: 370-391.

Wilbur, C.K. (1997). Revolutionary Medicine, 1700-1800. Guilford, CT: Globe Pequot Press.

Winter, D.G. (1973). The Power Motive. New York: The Free Press.

Wissler, R.L. (1995). "Mediation and adjudication in the small claims court: the effects of process and case characteristics," Law and Society Review, 29: 323-358.

Wood, R.E., P.W.B. Atkins and J.E.H. Bright (1999). "Bonuses, goals and instrumentality effects," Journal of Applied Psychology, 84: 703-720.

Yardley, J. (2006). "Deep in China, a poor and pious Muslim enclave," New York Times, 19 March: 1-10.

Zarankin, T. and J.A. Wall (2007). "Israeli and U.S. community mediation," International Negotiation, 12: 273-291. 


\section{References}

Azar, Edward E. (1982). The Codebook of the Conflict and Peace Data Bank (COPDAB). College Park, MD: Center for International Development, University of Maryland.

Bond, Doug, J. Craig Jenkins, Charles L. Taylor and Kurt Schock (1997). "Mapping mass political conflict and civil society: the automated development of event data," Journal of Conflict Resolution, 41(4): 553-579.

Brandt, Patrick T. and John R. Freeman (2006). "Advances in Bayesian time series modeling and the study of politics: theory testing, forecasting, and policy analysis," Political Analysis, 14(1): 1-36.

Brandt, Patrick T., Michael P. Colaresi and John R.R. Freeman (forthcoming). "Reciprocity, accountability and credibility in international relations," Journal of Conflict Resolution.

Davies, John L. and Chad K. McDaniel (1993). "The global event-data system,” in Richard L. Merritt, Robert G. Muncaster and Dina A. Zinnes (eds.) International Event-Data Developments: DDIR Phase II. Ann Arbor: University of Michigan Press, pp. 19-44.

Gerner, Deborah J. and Philip A. Schrodt (1998). "The effects of media coverage on crisis assessment and early warning in the Middle East," in Susanne Schmeidl and Howard Adelman (eds.) Early Warning and Early Response. New York: Columbia University Press, Columbia International Affairs Online.

Gerner, Deborah J., Philip A. Schrodt, Ronald A. Francisco and Judith L. Weddle (1994). "The machine coding of events from regional and international sources," International Studies Quarterly, 38: 91-119.

Gerner, Deborah J., Philip A. Schrodt, Ömür Yilmaz and Rajaa Abu-Jabr (2002). "The creation of CAMEO (Conflict and Mediation Event Observations): an event data framework for a post Cold War world," American Political Science Association, Washington. Online, available at: http://web.ku.edu/keds/paper.dir/ Gerner.APSA.02.pdf.

Gerner, Deborah J., Philip A. Schrodt, Ömür Yilmaz and Dennis Hermrick (2005). "The CAMEO (Conflict and Mediation Event Observations) actor coding framework," American Political Science Association, Washington.

Goldstein, Joshua S. and Jon C. Pevehouse (1997). "Reciprocity, bullying and international cooperation: a time-series analysis of the Bosnia conflict," American Political Science Review, 91 (3): 515-530.

Goldstein, Joshua S., Jon C. Pevehouse, Deborah J. Gerner and Shibley Telhami (2001). "Dynamics of Middle East Conflict and US Influence," Journal of Conflict Resolution, 45(5): 594-620.

Horowitz, Michael and Erin M. Simpson (2002). "Let's make a deal: modeling Israeli-Palestinian agreements, 1979-2002," Summer Conference on Political Methodology, Seattle, WA. 
Huxtable, Phillip A. (1997). Uncertainty and Foreign Policy-Making: Conflict and Cooperation in West Africa, $\mathrm{PhD}$ dissertation, University of Kansas.

King, Gary and Will Lowe (2003). "An automated information extraction tool for international conflict data with performance as good as human coders: a rare events evaluation design," International Organization, 57(3): 617-642.

Leng, Russell J. (1987). Behavioral Correlates of War, 1816-1975. ICPSR 8606. Ann Arbor: Inter-University Consortium for Political and Social Research.

McClelland, Charles A. (1976). World Event/Interaction Survey Codebook. ICPSR 5211. Ann Arbor: Inter-University Consortium for Political and Social Research.

McClelland, Charles A. (1983). "Let the user beware," International Studies Quarterly, 27(2): 169-177.

Pevehouse, Jon C. and Joshua S. Goldstein (1999). "Serbian Compliance or defiance in Kosovo? Statistical analysis and real-time predictions," Journal of Conflict Resolution, 43(4): 538-546.

Russett, Bruce M., J. David Singer and Melvin Small (1968). "National political units in the twentieth century: a standardized list," American Political Science Review, 62(3): 935-950.

Schrodt, Philip A. (2006). "Forecasting conflict in the Balkans using hidden Markov models," in Robert Trappl (ed.) Programming for Peace: Computer-Aided Methods for International Conflict Resolution and Prevention. Dordrecht, Netherlands: Kluwer Academic Publishers, pp. 161-184.

Schrodt, Philip A. and Deborah J. Gerner (1994). "Validity assessment of a machine-coded event data set for the Middle East, 1982-1992," American Journal of Political Science, 38(3): 825-854.

Schrodt, Philip A. and Deborah J. Gerner (1997). "Empirical indicators of crisis phase in the Middle East, 1982-1995," Journal of Conflict Resolution, 41 (4): 529-552.

Schrodt, Philip A. and Deborah J. Gerner (2000). "Cluster-based early warning indicators for political change in the contemporary Levant," American Political Science Review, 94(4): 803-818.

Schrodt, Philip A. and Deborah J. Gerner (2004). "An event data analysis of thirdparty mediation in the Middle East and Balkans," Journal of Conflict Resolution, 48(3): 310-330.

Schrodt, Philip A. and Ömür Yilmaz (2007). "Sub-state actor, temporal and geographical dimensions of the dissent-repression relationship: evidence from the Middle East," American Political Science Association, Chicago.

Schrodt, Philip A. and Ömür Yilmaz. (2008). CAMEO Conflict and Mediation Event Observations Codebook. Online, available at: http://web.ku.edu/keds/data.dir/ cameo.html.

Schrodt, Philip A., Shannon G. Davis and Judith L. Weddle (1994). "Political science: KEDS - a program for the machine coding of event data," Social Science Computer Review, 12(3): 561-588.

Shellman, Stephen and Brandon Stewart (2006). "Predicting risk factors associated with forced migration: an early warning model of Haitian flight," International Studies Association, San Diego.

Sherwin, Ronald and Lois Van Beers (1976). World Event/Interaction Survey Handbook and Codebook. Manuscript, Department of National Security Affairs, US Naval Postgraduate School, Monterey, CA.

Third Point Systems (1985). International Political Events Database Handbook, Version 1.0. Manuscript, Third Point Systems, Monterey, CA. 
304 D.J. Gerner et al.

Thomas, G. Dale (1999). The 'Strange Attractiveness' of Protracted Social Conflict in Northern Ireland. PhD dissertation, University of South Carolina.

Tomlinson, Rodney G. (1993). World Event/Interaction Survey (WEIS) Coding Manual. Manuscript, Department of Political Science, US Naval Academy, Annapolis, MD.

Wood, B. Dan and Jeffrey S. Peake (1998). "The dynamics of foreign policy agenda setting," American Political Science Review, 92(1): 173-184. 